\title{
Article \\ Autophagy Induction by Trichodermic Acid Attenuates Endoplasmic Reticulum Stress-Mediated Apoptosis in Colon Cancer Cells
}

\author{
Junyan $\mathrm{Qu}{ }^{1}$, Cheng Zeng ${ }^{1}$, Tingting Zou ${ }^{1}$, Xu Chen ${ }^{1}$, Xiaolong Yang ${ }^{2, *}$ and Zhenghong Lin ${ }^{1, *}$ \\ 1 School of Life Sciences, Chongqing University, Chongqing 401331, China; qujunyan1229@yeah.net (J.Q.); \\ cqzengcheng@163.com (C.Z.); tingtzou1997@163.com (T.Z.); chenxu_2021@163.com (X.C.) \\ 2 The Modernization Engineering Technology Research Center of Ethnic Minority Medicine of Hubei Province, \\ School of Pharmaceutical Sciences, South-Central University for Nationalities, Wuhan 430074, China \\ * Correspondence: yxl19830915@mail.scuec.edu.cn (X.Y.); zhenghonglin@cqu.edu.cn (Z.L.)
}

Citation: Qu, J.; Zeng, C.; Zou, T.; Chen, X.; Yang, X.; Lin, Z. Autophagy Induction by Trichodermic Acid Attenuates Endoplasmic Reticulum Stress-Mediated Apoptosis in Colon Cancer Cells. Int. J. Mol. Sci. 2021, 22, 5566. https://doi.org/10.3390/ijms 22115566

Academic Editor: Ireneusz Majsterek

Received: 21 April 2021

Accepted: 19 May 2021

Published: 25 May 2021

Publisher's Note: MDPI stays neutral with regard to jurisdictional claims in published maps and institutional affiliations.

Copyright: () 2021 by the authors. Licensee MDPI, Basel, Switzerland. This article is an open access article distributed under the terms and conditions of the Creative Commons Attribution (CC BY) license (https:// creativecommons.org/licenses/by/ $4.0 /)$.

\begin{abstract}
Colorectal cancer (CRC) is the third leading malignant tumor in the world, which has high morbidity and mortality. In this study we found that trichodermic acid (TDA), a secondary metabolite isolated from the plant endophytic fungus Penicillium ochrochloronthe with a variety of biological and pharmacological activities, exhibited the antitumor effects on colorectal cancer cells in vitro and in vivo. Our results showed that TDA inhibited the proliferation of colon cancer cells in a dose-dependent manner. TDA induces sustained endoplasmic reticulum stress, which triggers apoptosis through IRE1 $\alpha / \mathrm{XBP1}$ and PERK/ATF4/CHOP pathways. In addition, we found that TDA mediated endoplasmic reticulum stress also induces autophagy as a protective mechanism. Moreover, combined treatment of TDA with autophagy inhibitors significantly enhanced its anticancer effect. In conclusion, our results indicated that TDA can induce ER stress and autophagy mediated apoptosis, suggesting that targeting ER stress and autophagy may be an effective strategy for the treatment of CRC.
\end{abstract}

Keywords: TDA; ER stress; apoptosis; autophagy; colorectal cancer

\section{Introduction}

Cancer increasingly becomes the main cause of deaths around the world and the most important obstacle to improving life expectancy in the 21st century [1]. Colorectal cancer (CRC) is the third leading cancer among men and the second among women worldwide [2], with high incidence and low survival rate [3]. The incidence of CRC continues to increase at an alarming rate due to changes in modern urban lifestyles. The aging population and eating habits, obesity, lack of physical exercise, smoking and all the other unfavorable risk factors increase the risk of CRC [4]. At present, about 1.4 million of new patients are diagnosed with CRC every year, and the total annual death is about 700,000. With the continuous development of CRC in developing countries, it is estimated that by 2030, the global burden of CRC will increase by $60 \%$ to more than 2.2 million new cases and 1.1 million cancer deaths $[3,5]$. Currently, radiotherapy, surgery, immunotherapy and chemotherapy are commonly used methods for the treatment of CRC, but the survival rate of patients using these methods alone is not very satisfactory, and the 5-year survival rate of advanced patients is still less than $15 \%[4,6,7]$. In addition, many drugs used have serious side effects, including multidrug resistance, gastrointestinal toxicity and blood level decline, liver toxicity, which directly reduce the success rate of treatment [8-11]. For example, the incidence of thrombocytopenia in patients who received oxaliplatin in chemotherapy regimens was much higher than in patients who did not receive oxaliplatin, and the use of penfluorouracil often resulted in intestinal mucositis [10,11]. Therefore, the development of new and effective antitumor drugs is still an important strategy for the treatment of CRC. 
Trichodermic acid (TDA) is a natural product isolated from the solid-substrate fermentation culture of Penicillium ochrochloronthe associated the roots of Taxus media by our coworkers [12]. It has been reported that TDA has antibacterial, antifungal and antiinflammatory biological activities, and has obvious inhibitory ability on various cancer cells such as lung cancer, liver cancer, stomach cancer and colon cancer [12,13], showing its good potential to become a new anticancer drug. AMF-26, a derivative of TDA [14], has been shown to have good anticancer effects in many studies [15-20]. Among them, the disruption of endoplasmic reticulum to Golgi transport is the main mechanism of AMF-26's anticancer activity. This suggests that TDA may achieve its inhibitory effect on tumor cells by acting on the function of endoplasmic reticulum. In recent years, endoplasmic reticulum stress is also a hot topic in cancer treatment, which may be the potential targeting pathway of TDA.

Endoplasmic reticulum stress (ER stress) is a highly conservative cellular response. Proteins undergo specific signal pathways to fold, aggregate and transport in the endoplasmic reticulum, maintaining the dynamic balance of environmental material levels in the cell [21-23]. However, when some external stimuli break the balance of the ER, the protein synthesis signal will be interrupted, causing the accumulation of unfolded and misfolded proteins in the ER, disturbing the homeostasis and ultimately leading to ER stress [24-26]. Appropriate ER stress is conducive to the recovery of intracellular calcium ion and protein processing, and enhances the ability of cells to withstand stress stimulation. Severe and continuous ER stress often triggers cell apoptosis [27,28]. ER stress will activate a series of cellular regulatory mechanisms, the most typical of which is the unfolded protein response (UPR) [29]. UPR relieves stress in the early stage and triggers apoptosis when the homeostasis fails to maintain for a long time $[30,31]$.

UPR involves endoplasmic reticulum molecular chaperones (HSPA5/GRP78), endoplasmic reticulum stress sensor proteins (PERK, IRE1 $\alpha$ and ATF6) and their downstream signaling pathways $[32,33]$. Under normal conditions, these three transmembrane sensor proteins (PERK, IRE1 $\alpha$ and ATF6) bind to the ER molecular chaperone HSPA5 (also known as GRP78) and are in an inactive state [34]. In the process of ER stress, PERK dissociates from HSPA5 and activates ATF4, thereby promoting the transcription of genes related to cell survival and the proapoptotic factor CHOP [35]. After IRE1 $\alpha$ is activated, it can cut the mRNA encoding XBP1 to generate active transcription factor XBP1s (spliced XBP1, XBP1s). After XBP1s is translocated to the nucleus, it can upregulate the expression of genes related to ER stress [36]. IRE1 $\alpha$ can also induce cell apoptosis through TRAF2-activated JNK pathway and caspase-12 mediated signaling pathway [37]. After the dissociation of ATF6 and HSPA5, ATF6 will be transported from the ER to the Golgi to be cleaved and activated. The activated ATF6 enters the nucleus and alleviates ER stress from multiple levels by initiating a series of gene transcripts [38]. In addition to the two classic apoptosis pathways, the mitochondrial pathway and the death receptor pathway, apoptosis induced by ER stress is a common apoptotic pathway newly discovered in recent years. Additionally, it has been proved in many studies that ER stress-induced apoptosis is the molecular mechanism of many anticancer drugs [39]. Tunicamycin is an ER stress inducer, which can inhibit protein glycosylation and maturation in eukaryotes [40]. According to reports, tunicamycin reduces the proliferation, invasion and chemotaxis activities of breast tumor cells in nude mice [41]. In addition, Tunicamycin promotes the apoptosis of colon cancer cells through the AKT/mTOR signaling pathway and inhibits tumor growth in vivo and in vitro [42]. Combination therapy with tunicamycin, BAY 11-7082 and naringin induce ER stress and induce apoptosis of HT29 colon cancer cells through the PERK/eIF2 $\alpha /$ ATF4/CHOP pathway [43]. Cucurbitacin I can activate two of the three ERS pathways, IRE1 $\alpha$ and PERK and CHOP, thereby inducing apoptosis in SKOV3 and PANC-1 cells [44]. Recently, ER stress has also been reported as a major mechanism that celecoxib can induce cell death in cancer [45]. Therefore, activating the proapoptotic function of UPR through long-term or severe ER stress is considered to be an attractive cancer treatment strategy $[39,46]$. 
Meanwhile, the continuous stress of the endoplasmic reticulum may lead to autophagy. Autophagy is a self-degradation process that is important for balancing energy sources during the critical period of development and in response to nutritional stress $[47,48]$. During autophagy, the cytoplasmic contents of cells are sequestered in double-membrane vacuoles called autophagosomes, and then transported to lysosomes for degradation [49]. It is generally believed that under hypoxia, nutritional deficiencies, and anti-cancer treatments (such as chemotherapy and radiation therapy), cancer cells can continue to survive through autophagy [50-52]. The results of early clinical trials using hydroxychloroquine to treat cancer indicate that autophagy inhibition may be a promising method for the treatment of advanced cancer [53]. Studies have shown that autophagy has a dual role in promoting and inhibiting tumors in CRC [54-56], but its mechanism is still unclear. This difference in opposing effects is usually due to differences in the cells and tumor models used. This suggests that the role of autophagy in regulating cell death is highly dependent on cell type and stimulation conditions $[57,58]$. Therefore, further research on autophagy will reveal its potential therapeutic effects in diseases, and the regulation of autophagy may become a new direction for the drug development of cancer therapy $[59,60]$.

In this study, we found that TDA can significantly inhibit the growth of colon cancer cells both in vitro and in vivo. In vitro experiments have shown that TDA induces ER stressmediated apoptosis by upregulating the IRE1 $\alpha$ and PERK pathways and activating the subsequent $\mathrm{CHOP}$ and caspases proteins. At the same time, ER stress induces autophagy as a cytoprotective mechanism to reduce ER pressure. Therefore, treatment combined with autophagy inhibitors can enhance the anti-CRC effect of TDA both in vivo and in vitro. Overall, our results provide new insights into the molecular basis of CRC treatment and demonstrate the potential of TDA to treat cancer.

\section{Results}

\subsection{TDA Inhibits Colon Cancer Cell Viability In Vitro}

Trichodermic acid (TDA) is a natural product isolated from Penicillium ochrochloronthe, an endophytic fungus derived from Taxus media [12]. The chemical structure of TDA is shown in Figure $1 \mathrm{~A}$ and was characterized by comparison of its spectroscopic data (see Figures S1-S3) with those reported in the literature [13]. In previous studies, TDA has shown promising anticancer therapeutic potential. To determine the effect of TDA on colon cancer, we first evaluated the cell growth of two colon cancer cell lines (HCT116 and DLD1) and human colon mucosal epithelial cell line (NCM460) after TDA treatment. As revealed in Figure 1B-D, TDA inhibited the growth of colon cancer cells in a dose-dependent and time-dependent manner. The viability of HCT116 and DLD1 cells decreased rapidly in the presence of $1-6 \mu \mathrm{g} / \mathrm{mL}$ TDA, while NCM460 cells showed higher tolerance to TDA. At the same time, oxaliplatin, the standardized drug for colon cancer, was used as a comparison. As shown in Figure 1B,C, compared with oxaliplatin, colon cancer cells were more sensitive to the toxic response of TDA, which also proved its anticancer effect. According to the inhibitory ratio, we calculated that half-maximal inhibitory concentration $\left(\mathrm{IC}_{50}\right)$ of TDA toward HCT116 and DLD1 cells at $24 \mathrm{~h}$ were 3.410 and $3.866 \mu \mathrm{g} / \mathrm{mL}$, respectively. Based on the $\mathrm{IC}_{50}$ value, we choose $0,2,4$ and $6 \mu \mathrm{g} / \mathrm{mL}$ of TDA to conduct the following experiments. Consistently, the proliferation of colon cancer cells was significantly inhibited under TDA treatment, as evidenced by retarded cell growth (Figure 1E,F) and reduced colony formation (Figure 1G-J). At the same time, the proliferation of colon cancer cells decreased obviously with TDA treatment in a dose-dependent manner. Together, these results indicated that TDA exhibits a considerable anticancer effect in colon cancer cells in vitro. 
A<smiles>CC(=CC=CC1C(C)C=C[C@H]2CC(C)C(O)C(C)[C@]12C)C(=O)O</smiles>

B

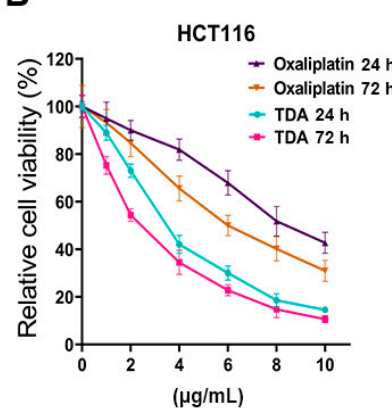

C

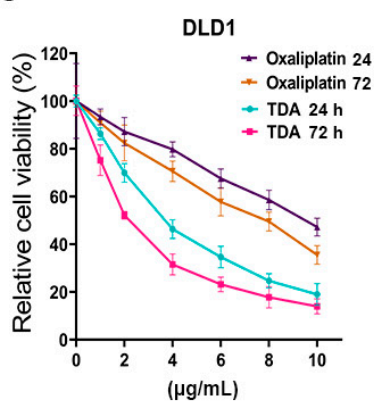

D

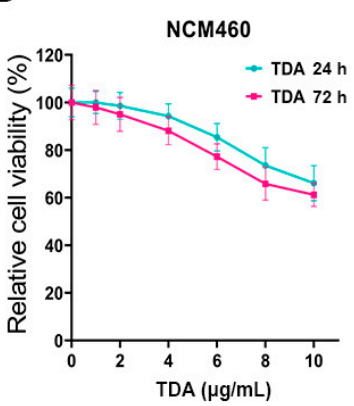

E

TDA $(\mu \mathrm{g} / \mathrm{mL})$

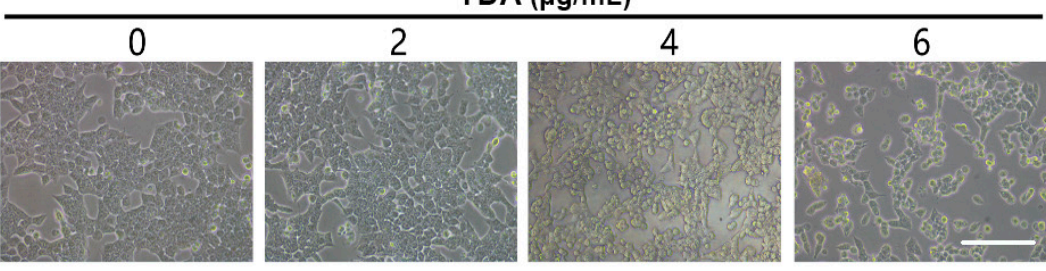

$\mathbf{F}$

HCT116

TDA $(\mu \mathrm{g} / \mathrm{mL})$

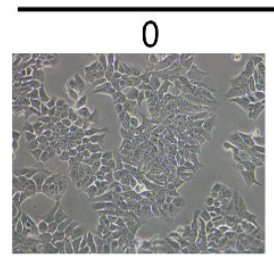

2
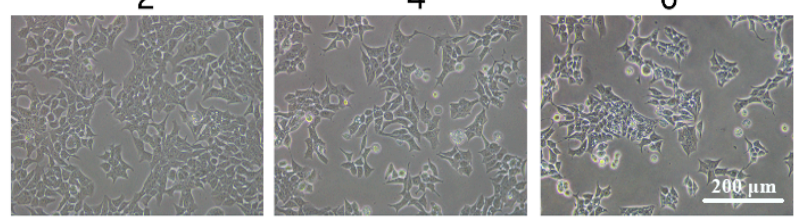

G
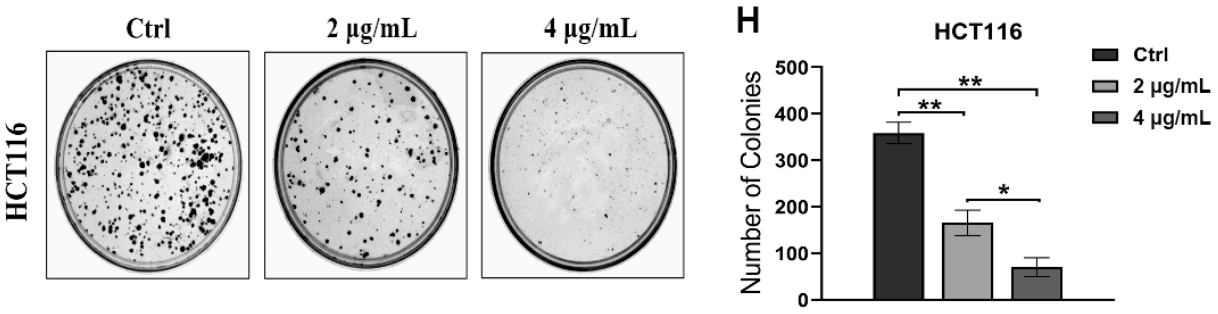

I
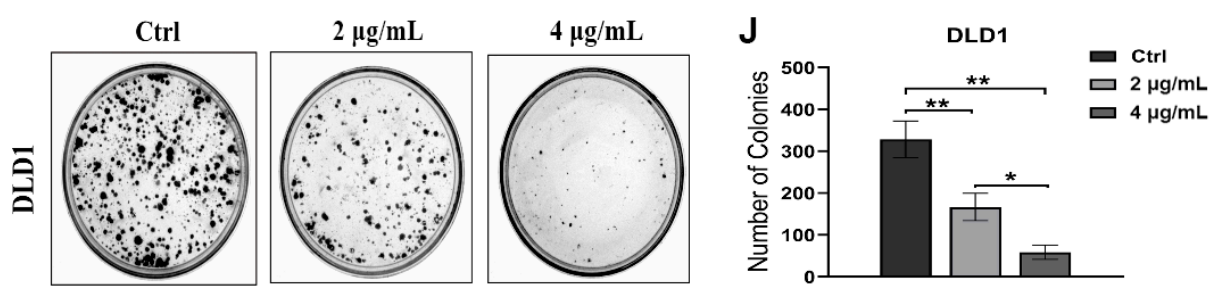

Figure 1. TDA inhibits cell viability in colon cancer cells. (A) The chemical structure of TDA. (B,C) HCT116 and DLD1 cells were treated with TDA or oxaliplatin $(0,1,2,4,6,8$ and $10 \mu \mathrm{g} / \mathrm{mL})$ for 24 or $72 \mathrm{~h}$, respectively. Cell viability was measured by CCK-8 assay. The absorbance was measured at $450 \mathrm{~nm}$. (D) NCM460 cells were treated with TDA (0, 1, 2, 4, 6, 8 and $10 \mu \mathrm{g} / \mathrm{mL}$ ) for 24 or $72 \mathrm{~h}$, respectively. Cell viability was measured by CCK-8 assay. The absorbance was measured at $450 \mathrm{~nm}$. (E,F) Morphological observation of colon cancer cells treated with TDA at indicated concentration. (G-J) Colony formation assay of HCT116 and DLD1 cells treated with the indicated concentrations of TDA. Representative images $(\mathbf{G}, \mathbf{I})$ and quantification of colonies $(\mathbf{H}, \mathbf{J})$ was shown. Data are presented as the mean $\pm \mathrm{SD}$ from at least three separate experiments. ${ }^{*} p<0.05 ; * * 0.01$.

\subsection{TDA Treatment Induces Cell Cycle Arrest and Apoptosis in Colon Cancer Cells}

Cell cycle arrest plays a key role in antitumor therapy, so we tested whether TDA treatment can induce cell cycle changes in colon cancer cells. Flow cytometry analysis showed that after TDA treatment, the proportion of cells in G0/G1 phase increased by $14.93 \%$ (HCT116) and $17.12 \%$ (DLD1) on average, while the total proportion of cells in the 
G2/M phase and S phase showed a significant downward trend (Figure 2A-D). Similarly, Western blot results showed an increase in CCNB1 level and a decrease in CCND1 level (Figure 2E), indicating that cell cycle was arrested in the G0/G1 phase with the TDA treatment. However, unlike TDA, the cell cycle of colon cancer under the influence of the standard drug oxaliplatin presents G2/M phase arrest (Figure S4), suggesting that TDA may have different therapeutic targets from oxaliplatin.
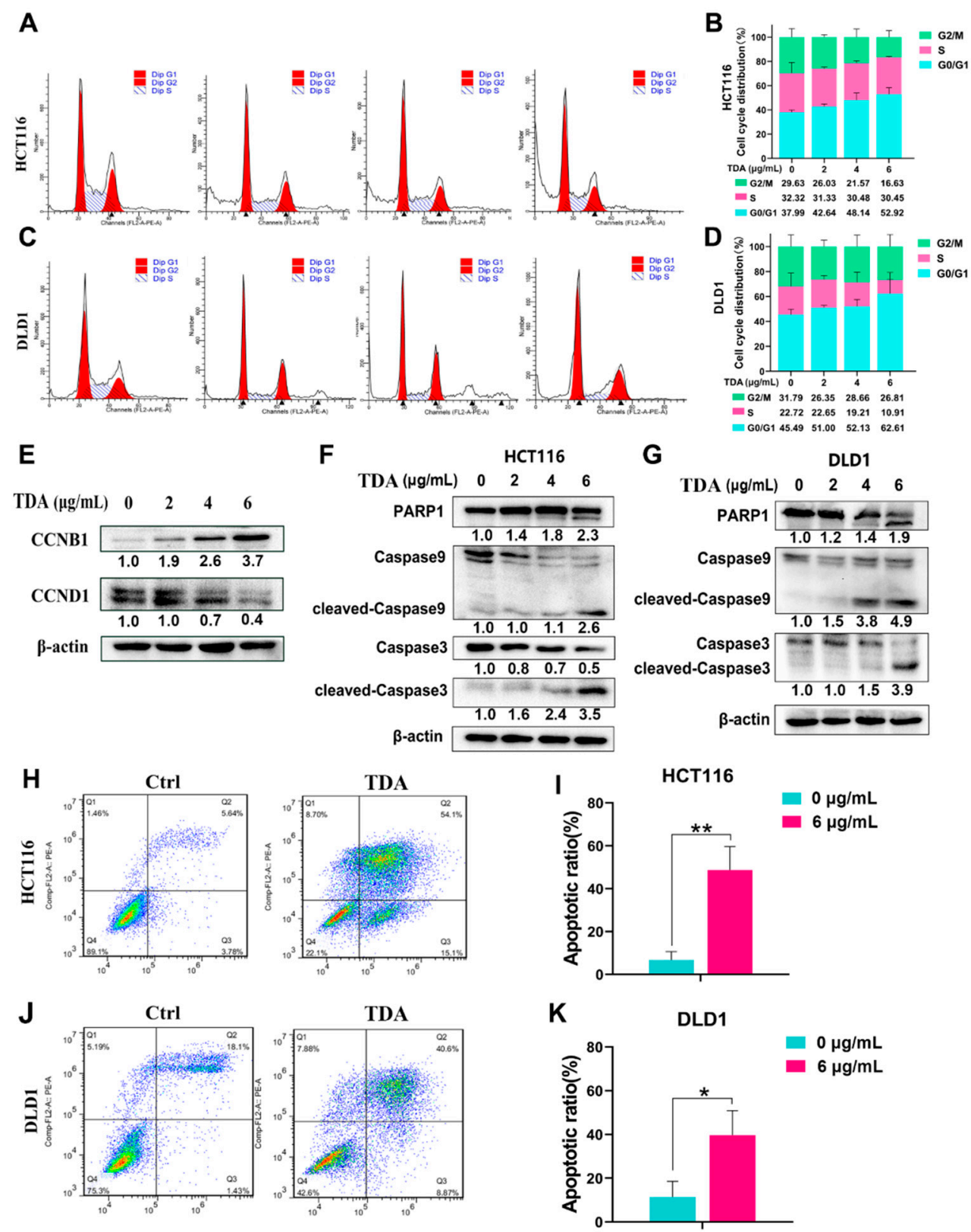

Figure 2. Flow cytometric analysis of colon cancer cells with TDA treatment. (A-D) Flow cytometric analysis of cell cycle in HCT116 and DLD1 cells upon TDA treatment as indicated concentration for $24 \mathrm{~h}$ was performed. (E) The expression of cyclin B1 and cyclin D1 in HCT116 cells with TDA treatment as indicated concentration for $24 \mathrm{~h}$ was detected by immunoblotting analysis. Beta-actin was used as internal control. (F,G) The protein expression levels of PARP1, cleaved PARP1, Caspase 9, cleaved Caspase 9, Caspase 3 and cleaved Caspase 3 in colon cancer cells treated with the indicated concentrations of TDA for $24 \mathrm{~h}$ were detected by Western blot. (H-K) Flow cytometric analysis of apoptosis in HCT116 and DLD1 cells upon TDA $(6 \mu \mathrm{g} / \mathrm{mL})$ treatment was performed for $24 \mathrm{~h}$. $(\mathbf{H}, \mathbf{J})$. The percentage of apoptotic HCT116 and DLD1 cells treated with TDA is shown $(\mathbf{I}, \mathbf{K})$. Western blot results were quantified using Image J software, and the results were numerically marked below each band. Data are presented as the mean \pm SD from at least three separate experiments. ${ }^{*} p<0.05 ;{ }^{* *} p<0.01$. 
To examine whether TDA induces apoptosis of colon cancer cells, we first examined the proapoptotic effect of TDA by examining the expression of apoptosis related genes. Using Western blotting, we measured the activation of apoptotic proteins caspase- 9 , caspase- 3 and PARP1. In HCT116 and DLD1, we found that the cleavage levels of caspase-9, -3 and PARP1 in cells treated with TDA were observably higher than those in untreated cells (Figure 2F,G). Next, we performed flow cytometry analysis by phosphatidylserine translocation using FITC-annexin V and propidium iodide (PI) double-staining. Consistent with the above results, our data showed a $30-40 \%$ increase in the percentage of apoptotic cells in the TDA treatment group, most of which occurred in the late apoptotic region (Figure $2 \mathrm{H}-\mathrm{K}$ ). Taken together, these results suggested that TDA can induce the apoptosis of colon cancer cells.

\subsection{Transcriptome Analysis Identified the Apoptotic-and Autophagy-Related Genes Contributive to the TDA-Induced Cell Death}

In order to explore the underlying mechanism of TDA inducing apoptosis of colon cancer cells, we used RNA sequencing (RNA-seq) to study the transcriptome of HCT116 cells treated with TDA $(4 \mu \mathrm{g} / \mathrm{mL})$ for $24 \mathrm{~h}$ in comparison with untreated control cells. The analysis identified 3136 differentially expressed genes $(p<0.05$, fold change $>2)$, of which 1066 were upregulated and 2070 were downregulated (Figure 3A). Differential gene enrichment analysis showed that TDA affected cellular components, biological processes and molecular functions by regulating 3136 genes in various pathways. The top 20 enriched by Gene Ontology have been listed (Figure 3B). Among them, endoplasmic reticulum unfolded protein response, response to endoplasmic reticulum stress and IRE1-mediated unfolded protein response occupy the top ones. At the same time, we observed that the transcription level of the ER stress related genes (HSPA5, PERK, CHOP, XBP1, etc.) significantly increased in the TDA treated cells (Figure 3C). In conclusion, we speculated that TDA induced ER stress in colon cancer cells. Accumulation of misfolded proteins can cause ER stress, which in turn induces an adaptive intracellular response known as UPR. However, when UPR cannot completely relieve ER stress, cells undergo apoptosis or autophagy. On the other hand, we found that autophagy-related genes (ATG and MAPILC3B) were also significantly upregulated in the TDA treatment group (Figure 3D), indicating that autophagy may be also involved in the toxic effect of TDA on colon cancer cells.

Next, we verified the results of transcriptome analysis by RT-PCR, and the mRNA levels of HSPA5, IRE1 $\alpha$, XBP1, PERK, ATF4 and CHOP all increased visibly in a timedependent manner. As expected, mRNA levels of HSPA5, PERK and IRE1 $\alpha$ had increased observably before $16 \mathrm{~h}$, while ATF 4 and CHOP showed a more significant increase at $24 \mathrm{~h}$, which was consistent with the action pattern of ER stress (Figure 3E). Moreover, LC3 and ATG5 expression were upregulated upon TDA treatment (Figure 3F). In summary, we hypothesized that TDA-induced apoptosis is achieved through the ER stress pathway, and autophagy is also involved in the process.

\subsection{TDA Induced Apoptosis through IRE1 $\alpha$ and PERK Pathways}

The ER is a highly dynamic organelle in eukaryotic cells. Many studies have shown that once UPRs (PERK, ATF6 and IRE1 $\alpha$ ) pathway are activated, they initiate early adaptive responses by increasing HSPA5 expression, thus regulating the transcription and translation of a series of genes. However, with prolonged stress, additional responses were activated, including caspase 12/9/3 and ATF4/CHOP, which promoted apoptosis. To determine whether TDA activates endoplasmic reticulum stress in colon cancer cells, we examined the expression of PERK, IRE1 $\alpha$, XBP1 and HSPA5 using Western blot. We observed elevated levels of these proteins after TDA treatment in a dose-dependent manner, indicating an activation of ER stress (Figure 4A,B). Meanwhile, we found that CHOP and cleaved-caspase 3 also increased after TDA treatment, further suggesting that TDA-induced ER stress leads to cell apoptosis (Figure 4C,D). 
A

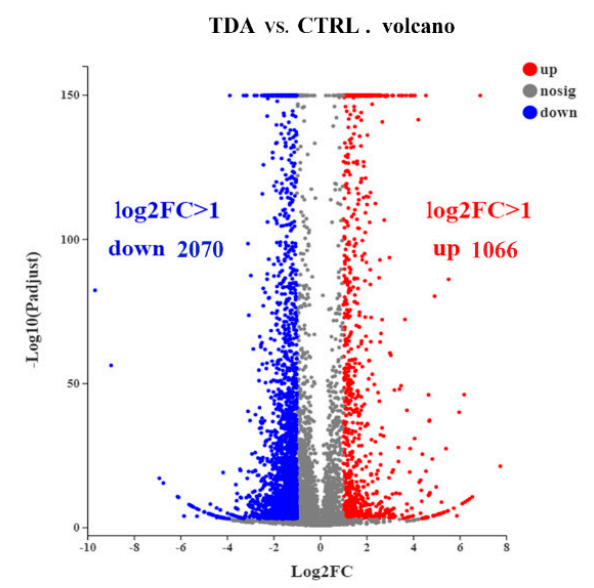

C

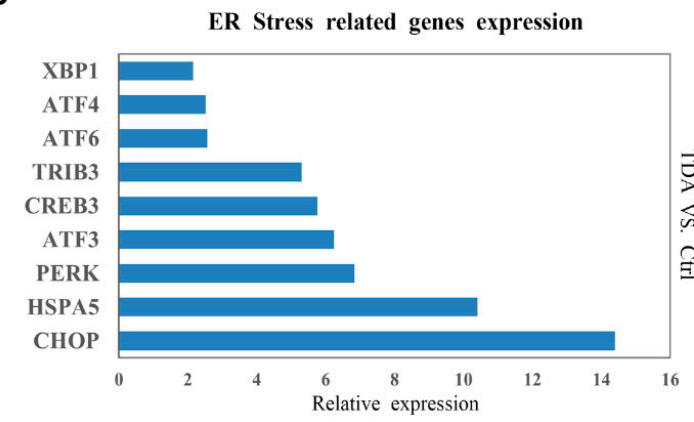

B

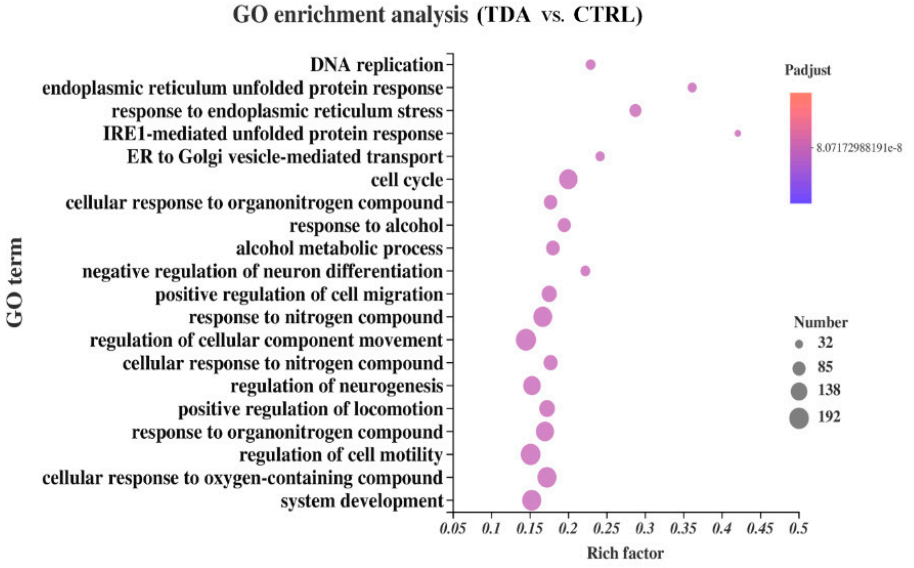

D

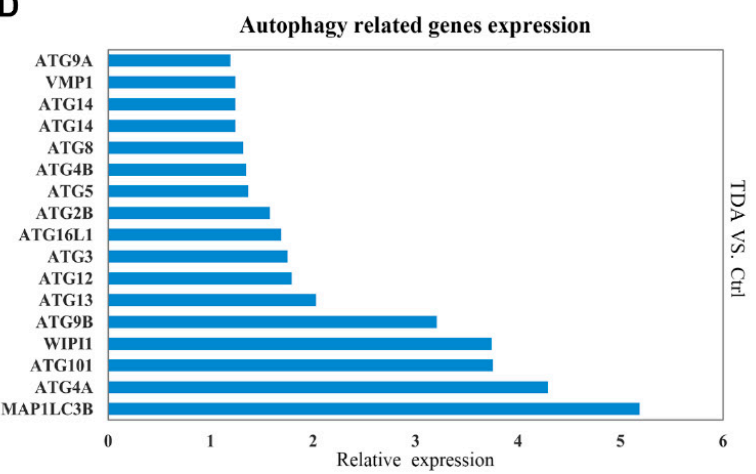

E
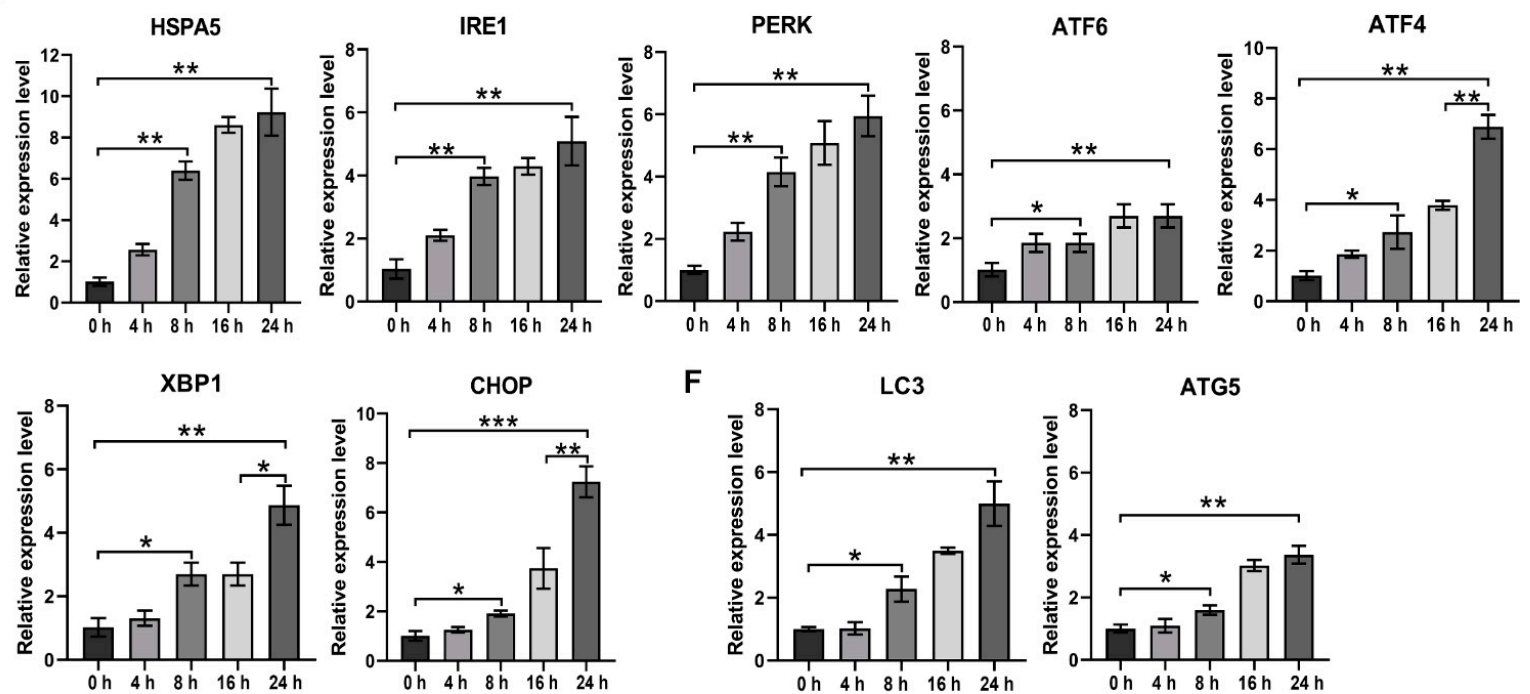

F
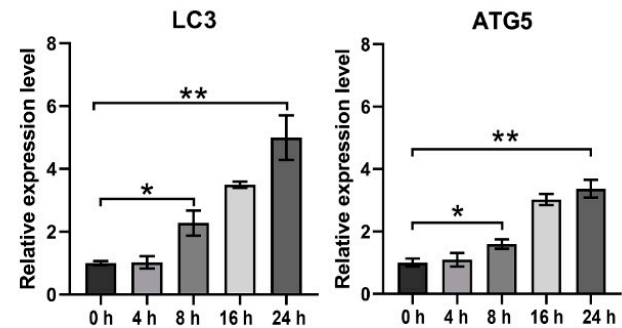

Figure 3. Transcriptome analysis of TDA-treated HCT116 cells. (A) The number of upregulated and downregulated differentially expressed genes in the transcriptome upon TDA $(4 \mu \mathrm{g} / \mathrm{mL})$ for $24 \mathrm{~h}$ treatment is shown in the volcano map. (B) GO enrichment analysis of the signaling pathways of differentially expressed genes in the transcriptome. (C) The relative expression of genes related to ER stress pathway in transcriptome analysis was shown. (D) The relative expression of autophagy related genes in transcriptome analysis was shown. (E,F) The mRNA level of ER stress related genes (E) and autophagy related genes $(\mathbf{F})$ were determined by real-time quantitative PCR after treatment with $6 \mu \mathrm{g} / \mathrm{mL}$ TDA for indicated time. Data are presented as the mean \pm SD from three separate experiments. ${ }^{*} p<0.05 ;{ }^{* *} p<0.01 ;{ }^{* * *} p<0.001$. 
A

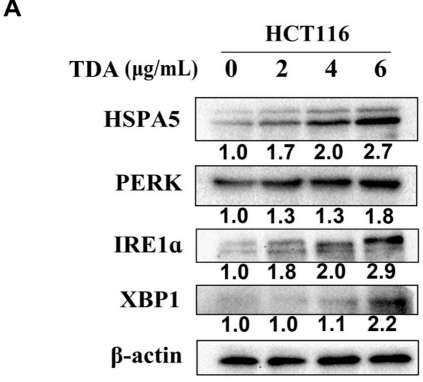

C

TDA $(\mu \mathrm{g} / \mathrm{mL}) \quad 0 \quad 2 \quad 4 \quad 6$

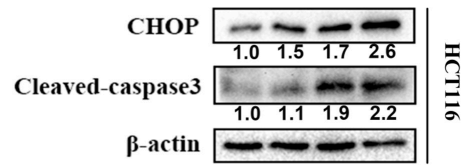

$\begin{array}{llllll}D & \text { TDA }(\mu \mathrm{g} / \mathrm{mL}) & 0 & 2 & 4 & 6\end{array}$
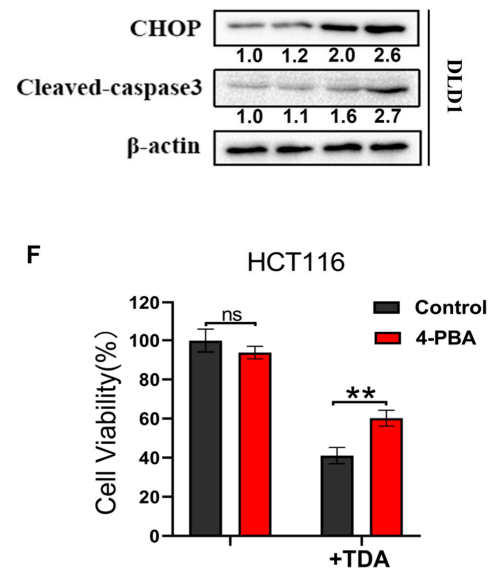

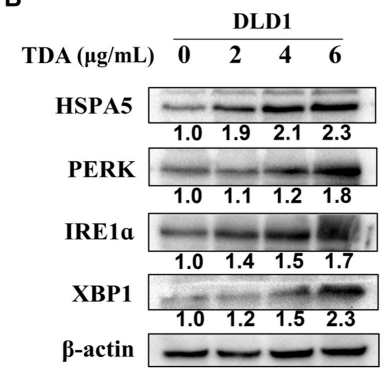

E

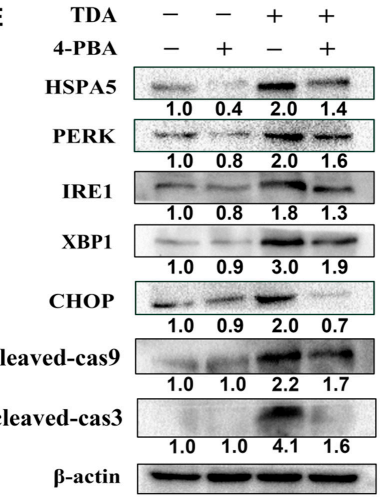

G

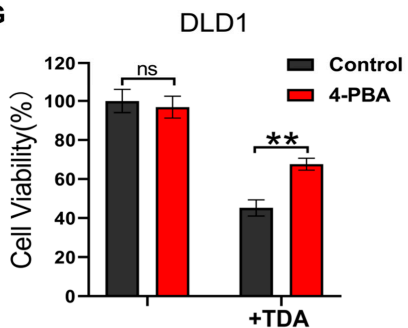

Figure 4. TDA activates ER stress response to induce apoptosis in colon cancer cells. $(\mathbf{A}, \mathbf{B})$ Western blot detection of the expression of HSPA5, PERK, IRE1 $\alpha$ and XBP1 in HCT116 and DLD1 cells treated with the indicated concentrations of TDA for $24 \mathrm{~h}$. (C,D) The protein expression levels of CHOP and cleaved Caspase 3 in TDA-treated HCT116 (C) or DLD1 (D) cells were detected by Western blot. (E) Western blot detection of the expression of HSPA5, PERK, IRE1 $\alpha$ and CHOP as well as cleaved Caspase 9 (cleaved-cas9), cleaved Caspase 3 (cleaved-cas3) in HCT116 cells treated with or without $6 \mu \mathrm{g} / \mathrm{mL}$ TDA in the presence or absence of $2 \mathrm{mM}$ 4-phenylbutyrate (4-PBA) for $24 \mathrm{~h}$. (F,G) Cell viability in HCT116 or DLD1cells treated with 4-PBA or TDA alone or together was measured by CCK-8 assay. Western blot results were quantified using Image J software, and the results were numerically marked below each band. Data are presented as the mean \pm SD from three separate experiments. ns, no statistical significance; ${ }^{* *} p<0.01$.

To evaluate whether ER stress plays a major role in TDA-induced apoptosis, HCT116 cells were treated with TDA combined with an ER stress inhibitor, 4-phenylbutyrate (4-PBA). As shown in Figure 4E, 4-PBA treatment significantly reduced the expression of HSPA5, PERK and IRE1 induced by TDA, while the protein levels of apoptosis-related proteins CHOP and cleaved caspase 3 also decreased under the combined treatment of 4-PBA. Importantly, by measuring cell viability by CCK-8, we observed that in the cells treated with TDA combined with 4-PBA, cell viability was increased compared with TDA alone, indicating that inhibition of endoplasmic reticulum stress reduced apoptotic proportion of the cells (Figure 4F,G). In summary, these results indicated that the endoplasmic reticulum stress pathway dominated the TDA-induced apoptosis of colon cancer cells. 


\subsection{Endoplasmic Reticulum Stress Induces Protective Autophagy}

Autophagy is an evolutionarily conserved mechanism that maintains cell homeostasis. More and more evidence suggest that ER stress-induced UPR activation promotes autophagy to coordinate ER homeostasis. We also observed upregulation of autophagyrelated genes in transcriptome data. Therefore, to clarify whether TDA induces autophagy in colon cancer cells, we analyzed the changes of autophagy flux with or without TDA treatment from three aspects. Firstly, fluorescence microscopy evaluation showed that the number of autophagosomes in TDA treated cells increased after $24 \mathrm{~h}$ treatment (Figure 5A). Secondly, we found that TDA induces the conversion of LC3-I to lipidated LC3-II (an established autophagosome marker) (Figure 5B,C). Thirdly, we evaluated the expression of autophagy-related proteins ATG5 and P62 (Figure 5B,C). ATG5 is a key protein involved in the formation of autophagosome, and P62 is a marker of autophagy degradation. When autophagy is triggered, P62 is decreased and when autophagy is inhibited, P62 accumulates. The results showed that TDA significantly reduced P62 levels. In contrast, TDA increased the expression of ATG5 (Figure 5B,C). Taken together, these data suggest that TDA induces autophagy in colon cancer cells.

To investigate whether autophagy induction is an adaptive process in response to ER stress, we examined the expression of autophagy-related proteins in HCT116 cells treated with TDA alone and in combination with 4-PBA. As shown in Figure 5D, 4-PBA inhibited TDA-induced upregulation of autophagy-related proteins. In contrast, the autophagy inhibitor chloroquine (CQ) had no significant effect on the expression of ER stress markers in TDA-treated cells (Figure 5E). These data indicated that TDA-induced ER stress is an upstream event of autophagy.

Abnormal autophagy plays a dual role in promoting cancer cell survival and cell death in colon cancer. To elucidate the role of TDA in inducing autophagy in colon cancer cells, we treated cells with TDA alone or in combination with autophagy inhibitor 3-methyladenine (3-MA) or CQ. As shown in Figure 5F,G, an increase in cell toxicity were observed following CQ or 3-MA treatment in TDA-treated colon cancer cells. This suggested that TDA-induced autophagy is protective but not harmful in colon cancer cells.

\subsection{Treatment of TDA Retards the Growth of Transplanted Tumors}

In order to further test the anticancer effect of TDA in vivo, we subcutaneously inoculated human colon cancer HCT116 cells into 6-week-old nude mice to establish a xenograft tumor model. Compared with the control group, xenograft tumors treated with TDA alone showed a significant reduction in volume, growth rate and weight (Figure 6A-C). Notably, the efficacy of TDA was reduced in combination with 4-PBA compared to TDA alone (Figure 6A-C). In contrast, the size, growth rate and weight of xenograft tumors treated with TDA combined with CQ were further reduced (Figure 6D-F). In addition, obvious ER stress and apoptosis were observed in mouse tumors treated with TDA, as evidenced by increased HSPA5 and cleaved-caspase- 3 levels in immunohistochemistry, while single treatment of TDA displayed more robust cleaved-caspase 3 staining (Figure 6G), which further proved that the apoptosis induced by TDA is dominated by the ER stress pathway. We also observed an increase in LC3B expression and a decrease in P62 expression by immunohistochemical staining (Figure $6 \mathrm{H}$ ). These results suggest that $\mathrm{CQ}$ enhances the antitumor effect of TDA by inhibiting autophagy of colon cancer cells. 
A
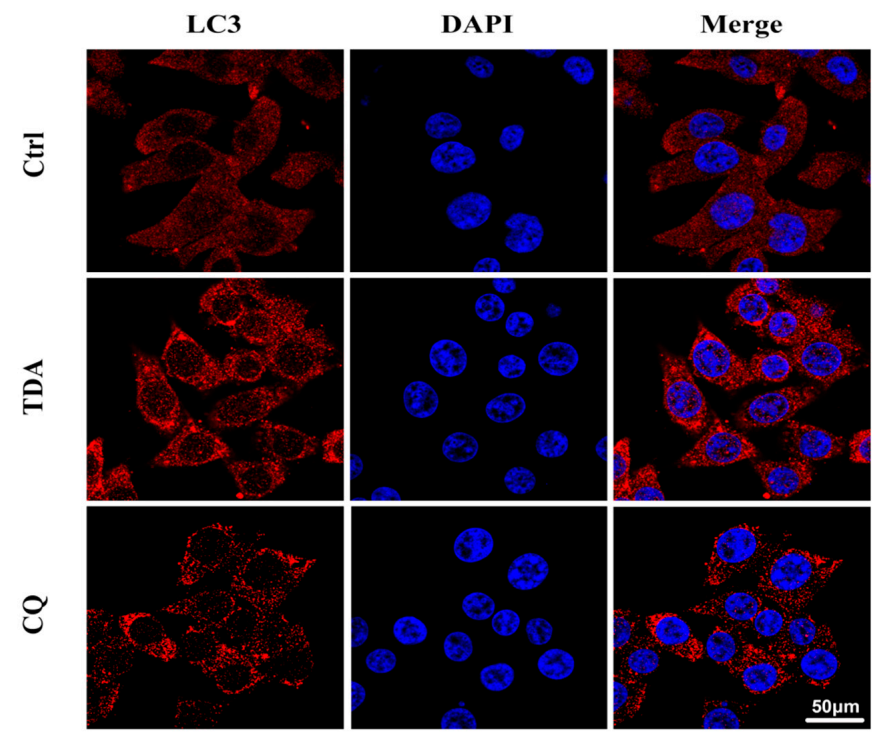

B

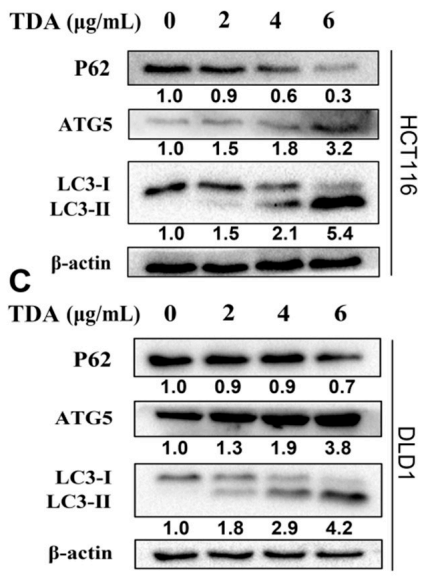

F

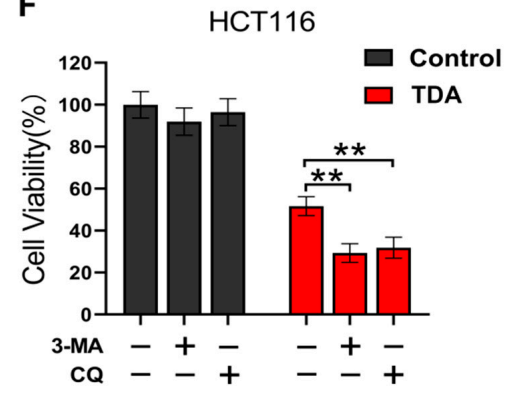

D
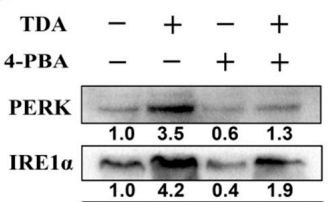

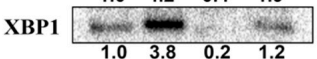

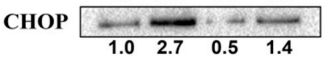

LC3-I
LC3-II

P62

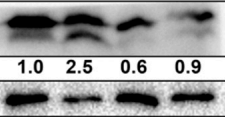

$\beta$-actin
E

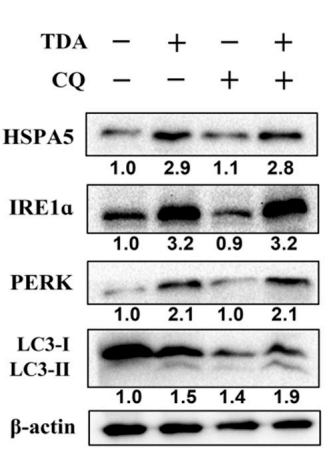

G

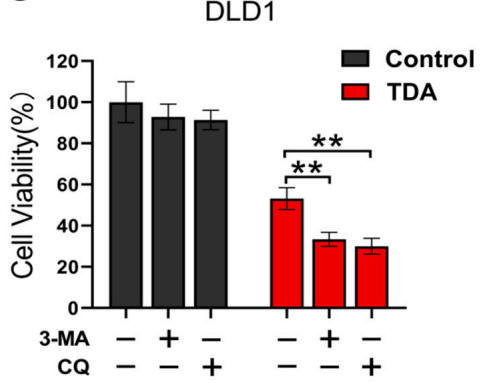

Figure 5. TDA induces autophagy in colon cancer cells. (A) Analysis of autophagy induction by immunofluorescence staining of LC3B in HCT116 cells, which were treated with TDA $(3 \mu \mathrm{g} / \mathrm{mL})$ for $24 \mathrm{~h}$. CQ $(10 \mu \mathrm{M})$ was treated for $24 \mathrm{~h}$ as a positive control. $(\mathbf{B}, \mathbf{C})$ The protein expression levels of P62, ATG5 and LC3 in TDA-treated HCT116 or DLD1 cells were detected by Western blot. (D) Immunoblotting of PERK, IRE1 $\alpha$, LC3 and P62 in HCT116 cells treated with TDA, 4-PBA alone or together as indicated for $24 \mathrm{~h}$. (E) Immunoblotting of HSPA5, PERK, IRE1 $\alpha$ and LC3B in HCT116 cells treated with TDA, CQ alone or together as indicated for $24 \mathrm{~h}$. (F,G) HCT116 and DLD1 cells were treated with TDA alone or combination with autophagy inhibitors 3-MA or CQ as indicated. Cell viability was measured by CCK-8 assay. Cells were pretreated with 3-MA (1 mM) or CQ $(10 \mu \mathrm{M})$ for $4 \mathrm{~h}$, followed by TDA $(6 \mu \mathrm{g} / \mathrm{mL})$ treatment for $24 \mathrm{~h}$. Data are presented as mean $\pm \mathrm{SD}$. ${ }^{* *} p<0.01$. Western blot results were quantified using software Image J v1.8.0 (National Institutes of Health, USA) and the results were numerically marked below each band. 
A

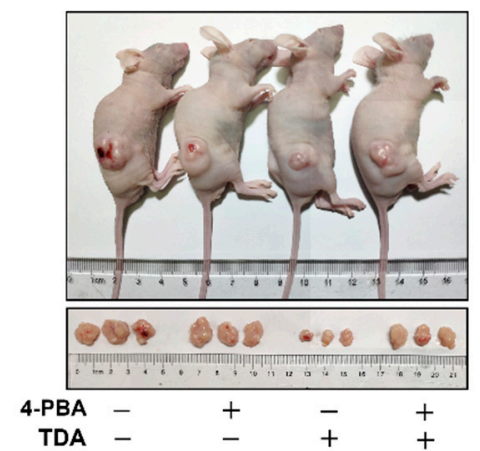

D

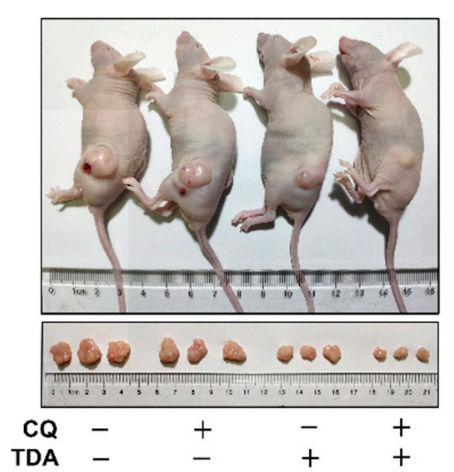

B

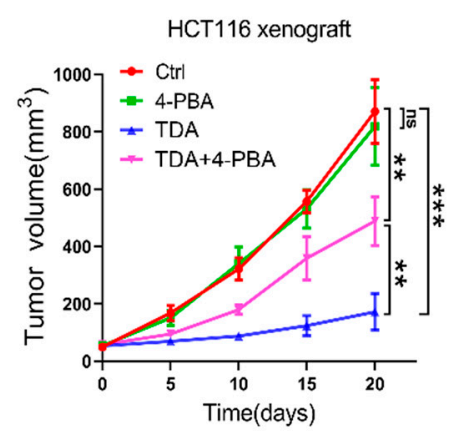

E

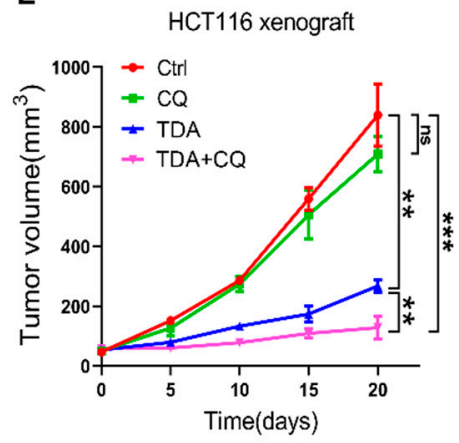

C

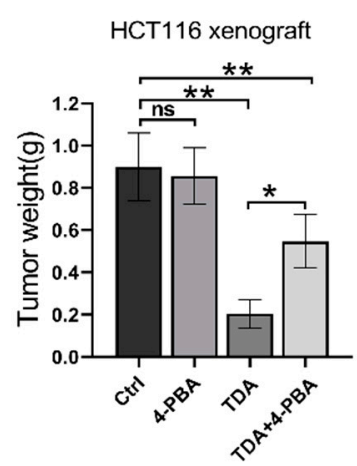

F

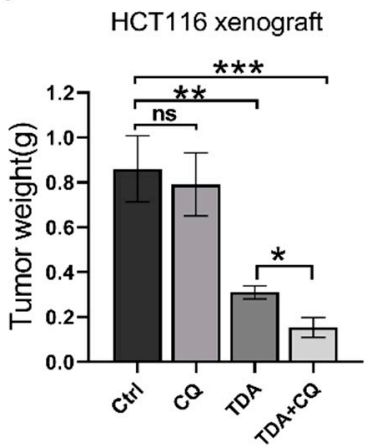

G Ctrl

4-PBA

TDA

TDA+4-PBA

cleaved-
Caspase 3
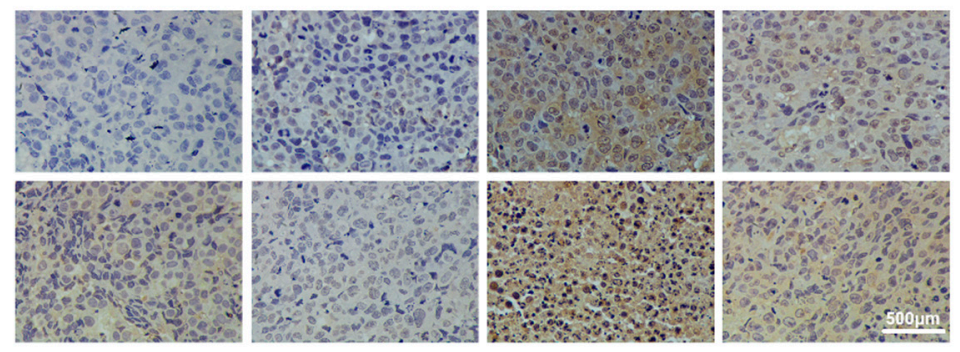

HSPA5

Ctrl
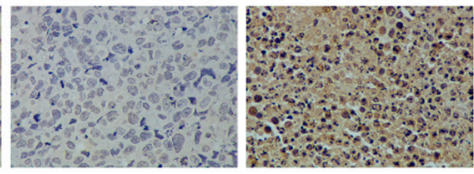

CQ

TDA

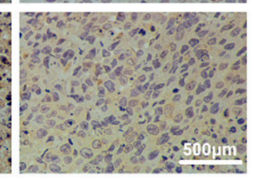

H

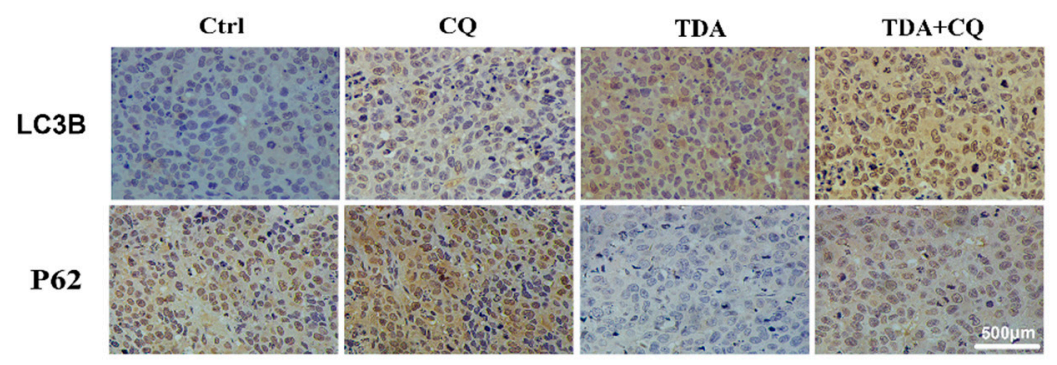

Figure 6. TDA inhibits the tumor growth in vivo. HCT116 cells were injected subcutaneously into 6-week-old nude mice. (A-C) When the tumor volumes reached $100 \mathrm{~mm}^{3}$, mice were treated with TDA alone or combination with 4-PBA as indicated. Images (A) and tumor weight (B) and volumes measured every 5 days (C) were shown. (D-F) When the tumor volumes reached $100 \mathrm{~mm}^{3}$, mice were treated with TDA alone or combination with CQ as indicated. Images (D) and tumor weight $(\mathbf{E})$ and volumes measured every 5 days $(\mathbf{F})$ were shown. $(\mathbf{G}, \mathbf{H})$ Immunohistochemical staining analysis was performed to detect the expression of cleaved Caspase3, HSPA5 (G), LC3B or P62 (H). Data are presented as mean \pm SD. ns, no statistical significance; ${ }^{*} p<0.05 ;{ }^{* *} p<0.01 ;{ }^{* * *} p<0.001$.

\section{Discussion}

CRC is still one of the notorious cancers at present [4]. Although the current research made significant progress in the mechanism understanding of tumorigenesis and developed multiple treatments such as surgery, radiotherapy and chemotherapy, the 5-year 
survival rate of advanced stage patients is still less than 15\% [6,7]. This low survival rate is due to late diagnosis and resistance to current chemotherapy [9]. Therefore, new and effective treatment approaches are still essential and urgent.

In recent years, natural products have aroused people's interest in the development of new anticancer therapeutic drugs [61-63], because most of them show good potential of medicinal significance, which can be used as alternative drugs for the treatment of various diseases (including cancer) with few side effects relatively [64,65]. TDA is a newly discovered octahydronaphthalene derivative, isolated from the secondary metabolites of plant endophytic fungi, and has shown anticancer activity in a variety of cancers [12,13]. However, until now, the anticancer mechanism of TDA remains unclear. Therefore, in this study, we explored the antitumor activity and molecular mechanism of TDA in colon cancer. At first, we found that genes related to ER stress pathway and autophagy pathway were significantly activated in TDA treated cells through transcriptome analysis. In subsequent studies, we mainly analyzed the death-promoting mechanism of TDA from these two aspects.

Recently, ER stress and unfolded protein response (UPR) have attracted extensive attention as targets of tumor therapy $[39,66]$. The ER is responsible for the correct folding and post-translational modification of proteins, calcium storage and lipid synthesis [22,23]. The disturbance of ER homeostasis usually leads to ER stress, and UPR is activated to relieve ER pressure. PERK, IRE1 $\alpha$ and ATF6 are sensors of ER stress and markers of UPR. They can promote transcription of genes responsible for maintaining ER homeostasis, but under certain conditions, they may extend ER stress and eventually lead to the proapoptotic pathway $[24,28,46]$. In our study, the protein expression levels of PERK, IRE1 $\alpha$ and XBP1 were significantly increased after TDA treatment. Meanwhile, the apoptotic marker CHOP and caspase protein were also activated, indicating that the proapoptotic pathway of ER stress had been triggered. In addition, the combined treatment of ER stress inhibitor 4-PBA and TDA attenuated the therapeutic effect of TDA, further demonstrating that the activation of UPR dominates the apoptosis induced by TDA. According to the survival curve of colon cancer patients, patients with high expression of ER stress-related proteins such as HSPA5, IRE $1 \alpha$ and PERK have a higher survival time than those with low expression, suggesting that UPR activation may have a potential tumor suppressive effect, especially when ER stress intensity is high and persistent.

Due to the harsh living environment of tumor cells, most malignant tumor cells themselves have slight chronic ER stress, and ER chaperone HSPA5 is often highly expressed in tumor cells [67]. ER stress-induced cell death is controlled by many factors, including calcium ions, reactive oxygen species and proapoptotic proteins [68]. Among them, CHOP is a key protein in this process [69]. Despite tumor cells have mild ER stress, the expression of CHOP is still at a low level. However, levels of CHOP and other apoptotic proteins were greatly increased in severe ER stress. The extent and duration of this increase is a determining factor in the cell fate [70,71]. Therefore, it may be an opportunity for therapeutic interventions to further aggravate the existing stress conditions in tumor cells by appropriate drugs, forcing the ER stress response into a proapoptotic mode. At present, many drugs have been used to induce apoptosis of the ER stress pathway. These drugs are also called ER stress aggravating agents (ERSA) [72], such as drugs perturbing calcium levels (thapsigargin, ionomycin and A-23187) [73,74], impairment of protein folding (2-deoxyglucose, tunicamycin and geldanamycin) $[73,75,76]$ and inhibiting protein trafficking (brefeldin A and monensin) [77,78]. Among them, thapsigargin, tunicamycin and brefeldin A are the most widely used [39]. Current research is trying to use these compounds in clinical anticancer applications, but unfortunately, most of the drugs have been shown to have systemic toxicity in clinical animal studies $[79,80]$. In addition, a few FDA-approved drugs have also been found to have ERSA activity, such as celecoxib and bortezomib, although this activity was not discovered until after the main pharmacological action had been approved by the FDA $[45,81,82]$. In conclusion, there is still a long way to go for ER stress to establish a clinical treatment effect. 
On the other hand, autophagy is also an important regulatory factor in the occurrence and development of cancer. Apoptosis and autophagy interact in both normal physiology and a wide range of diseases, and are crucial in determining the fate of cells [48,57]. Up to now, there is no research report that autophagy occurs in cancer cells after TDA treatment. In this study, we found that after TDA treatment of colon cancer cells, LC3-I conversion to LC3-II increased, the expression of P62 decreased and the number of autophagosomes also showed an increase as determined by immunofluorescence staining, indicating that TDA induced autophagy. Autophagy removes damaged organelles through lysosomal degradation and retrievals components to meet cellular metabolic needs [47]. Therefore, autophagy is essential for homeostasis and mediates resistance to radiation, chemotherapy and some targeted therapies [83]. More and more evidence show that autophagy inhibitors such as bafilomycin A1 and chloroquine (CQ) can enhance the effects of different cancer treatments, and clinical trials have been initiated [84]. However, the role of autophagy in cancer remains controversial. Some studies have suggested that cancer cells develop autophagy as a temporary survival mechanism after antitumor drug therapy $[85,86]$. Oppositely, some treatments can induce autophagic death or both apoptosis and autophagic death $[87,88]$. Thus, the exact role of autophagy appears to be highly dependent on cell type and environment. In order to further study the interaction between autophagy and apoptosis under TDA treatment, we pretreated HCT116 cells with autophagy inhibitors. HCT116 cells are more sensitive to TDA treatment, and the proportion of apoptotic cells increases. It shows that TDA-induced autophagy is cytoprotective. Therefore, joint treatment with autophagy inhibitors can make TDA achieve the best therapeutic effect.

In recent years, many studies have shown that ER stress can act as an upstream target of autophagy. The molecular mechanisms of ER stress induced autophagy include UPR, $\mathrm{Ca}^{2+}$ imbalance and Bcl-2 [89-91]. After we pretreated cells with ER stress inhibitors, the level of TDA-induced autophagy decreased, suggesting that TDA-induced autophagy was most likely to occur through ER stress, but the exact mechanism has still not been revealed. Clearly, more research is needed to determine the role of autophagy in TDAtreated cancer cells.

\section{Materials and Methods}

\subsection{Animal Study}

Animal experiments were conducted under the guidance of Animal Management Regulations in Chongqing University. In vivo tumorigenesis assays were conducted as previously described [92]. When the tumor volume reached about $50 \mathrm{~mm}^{3}$, mice were randomly divided into four groups and subcutaneously injected with TDA, TDA/4-PBA, TDA/CQ or PBS every two days. Tumor volume was measured every five days. The mice were sacrificed after twenty days of treatment, and tumors were harvested.

\subsection{Cell Culture and Reagents}

Human colon cancer cell lines (HCT116 and DLD1) were purchased from Procell Company (Wuhan, China) and human colon mucosal epithelial cell line (NCM460) were purchased from Fenghui Biotechnology (Hunan, China). All cells were cultured in DMEM containing $10 \%$ fetal bovine serum (FBS) and $100 \mathrm{U} / \mathrm{mL}$ mixture of penicillin and streptomycin. The TDA is provided by the School of Pharmacy, Chongqing University. Cell counting kit 8 was purchased from MCE. Annexin V-FITC/PI Apoptosis Detection kit was purchased from CWBIO (Beijing, China). Primary antibodies for Western blotting, immunofluorescence and immunohistochemistry against target proteins are shown as follows: Caspase9/P35/P10 (Proteintech, Chicago, IL, USA, 66169), Caspase3 (Zen Bioscience, Chengdu, China, 300968), cleaved-Caspase3 (Zen Bioscience, 380169), PARP1 (Zen Bioscience, 380451), LC3 (Sangon Biotech, Shanghai, China, D163557), ATG5 (Sangon Biotech, D121650),SQSTM1/p62 (Beyotime, Shanghai, China, AF5312), $\beta$-actin (Santa Cruz, sc-47778), cyclinD1 (Cell Signaling Technology, USA, 2978S), cyclinB1 (Cell Signaling Technology, 4135S), PERK (Cell Signaling Technology, 3192S), IRE1 (Zen Bio- 
science, 220399), XBP1(Zen Bioscience, 381710), CHOP (Zen Bioscience, 381679) and HSPA5 (Sangon Biotech, D260466).

\subsection{Cell Viability and Colony Formation Assay}

Cell viabilities were assessed by cell counting kit 8 (CCK8) assay. Cells were seeded in 96-well plates at a concentration of $5 \times 10^{3}$ per well. After the cells adhered to the wall, the cells were treated with different concentrations of TDA and cultured for $48 \mathrm{~h}$. Then, CCK8 was added and incubated at $37^{\circ} \mathrm{C}$ for $2 \mathrm{~h}$ and absorbance value was measured at $450 \mathrm{~nm}$ of wavelength. Colony-formation assay was conducted as previously described [93]. Colonies with more than 50 cells were counted.

\subsection{Flow Cytometric Analysis}

HCT116 and DLD1 cells were seeded into a 6-well plate, attached overnight and were treated with TDA for $24 \mathrm{~h}$. Then, cells were collected and stained with Annexin V-FITC/PI apoptosis detection kit and subjected to an apoptosis assay. Cell cycle analysis were conducted as previously described [94], cells were incubated with indicated concentration of TDA for $24 \mathrm{~h}$, cells were rinsed in precooled PBS and followed by fixed with $75 \%$ alcohol overnight at $4{ }^{\circ} \mathrm{C}$. Then cells were digested with $1 \%$ RNase A and stained with $1 \mathrm{mg} / \mathrm{mL}$ PI for $30 \mathrm{~min}$. All of these experiments were performed according to the corresponding manufacturer's instructions. Experimental data were analyzed using Flow Jo VX (Becton, Dickinson and Company, Franklin Lake, NJ, USA) and ModiFit LT 4.1 (Verity Software House, Topsham, ME, USA).

\subsection{Western Blotting Analysis}

Protein extraction and Western blot analysis were conducted as previously depicted [93]. Cells were rinsed in precooled PBS and proteins were extracted using RIPA lysis buffer (150 mM NaCl, $50 \mathrm{mM}$ Tris-HCl, $\mathrm{pH}$ 8, 0.5\% sodium deoxycholate, 1\% NP-40, 0.2\% SDS) containing protease inhibitor cocktail (EDTA free) (MedChemExpress, HY-K0011). After centrifugation $(13,000 \times g, 10 \mathrm{~min})$, total proteins were quantified with BCA Protein Assay Kit (CWBIO, Beijing, China, CW0014). Equal amounts of protein samples (30-80 $\mu \mathrm{g})$ were separated on SDS-PAGE gels and then transferred to $0.45 \mu \mathrm{m}$ PVDF membranes (GE Healthcare, Erlangen, Germany, A29280264). After incubation of the membranes with primary antibodies $(1: 1000)$ at $4{ }^{\circ} \mathrm{C}$ overnight, the samples were incubated with the secondary antibodies (1:5000) conjugated with horseradish peroxidase for $1 \mathrm{~h}$ at room temperature. The blots were visualized with WesternBright ${ }^{\mathrm{TM}} \mathrm{ECL}$ reagent (advansta, Bering Dr, San Jose, CA, USA, 191026-11) using ChemiDoc ${ }^{\mathrm{TM}}$ XRS+ (Bio Rad, Berkeley, CA, USA).

\subsection{Real-Time PCR Analysis}

Total RNA was extracted using trizol reagent as described [93], quantitative realtime PCR was performed using SYBR-Green qPCR master mix. $\beta$-actin was used to normalize sample. The RT-PCR primers were used as follows: HSPA5, forward: CTGTCCAGGCTGGTGTGCTCT, reverse: CTTGGTAGGCACCACTGTGTTC, PERK, forward: GTCCCAAGGCTTTGGAATCTGTC, reverse: CCTACCAAGACAGGAGTTCTGG, IRE1, forward: CACCTCCACTCCCTCAACAT, reverse: CTTCTTGCAGAGGCCAAAGT, ATF6, forward: CAGACAGTACCAACGCTTATGCC, reverse: GCAGAACTCCAGGTGCTTGAAG, XBP1, forward: GTTGGGCATTCTGGACAACT, reverse: AAGGGAGGCTGGTAAGGAAC, ATF4, forward: TTCTCCAGCGACAAGGCTAAGG, reverse: CTCCAACATCCAATCTGTCCCG, CHOP, forward: CAGAACCAGAGGTCACA, reverse: AGCTGTGCCACTTTCCTTTC, LC3, forward: GAGAAGCAGCTTCCTGTTCTGG, reverse: GTGTCCGTTCACCAACAGGAAG, ATG5, forward: CCCTCTTGGGGTACATGTCT, reverse: CGTCCAAACCACACATCTCG, $\beta$-actin, forward: CCTAGAAGCATTTGCGGTGG, reverse: GAGCTACGAGCTGCCTGACG. 


\subsection{Confocal Microscopy Imaging}

To evaluate the expression level of endogenous LC3, we treated cells with TDA for $24 \mathrm{~h}$, and then fixed with $4 \%$ paraformaldehyde and permeabilized with $0.2 \%$ Triton X-100, followed by blocking with $10 \%$ goat serum, cells were incubated with anti-LC3 antibody (1:200) and Alexa Fluor 555 goat anti-mouse $\operatorname{IgG}(\mathrm{H}+\mathrm{L})$ antibody, then images were visualized under confocal microscopy [92].

\subsection{Immunohistochemistry}

Tumors obtained from HCT116 xenograft mice were fixed with $4 \%$ paraformaldehyde, embedded in paraffin and sectioned. Tumor slides were incubated overnight with the primary antibody at $4{ }^{\circ} \mathrm{C}$ and then incubated with a secondary antibody, and the chromogenic reaction was conducted with 3,3-diaminobenzidine and counterstained with hematoxylin.

\subsection{Statistical Analysis}

A two-tailed Student's paired $t$-test and one-way ANOVA were used for statistical analysis of experimental data and data were expressed as mean \pm SEM of at least three independent experiments. A value of $p<0.05$ was considered statistically significant.

\section{Conclusions}

In summary, our results indicate that TDA may be a promising anticancer drug for the treatment of colon cancer, and excessive endoplasmic reticulum stress may be a key molecular event in the anticancer effect of TDA. TDA-induced ER stress leads to apoptosis through the IRE1/XBP1 pathway and the PERK/CHOP pathway. Interestingly, TDAinduced ER stress also triggered autophagy, which plays a protective role in response to ER stress, while the combination of autophagy inhibitors can significantly enhance the anticancer effect of TDA on colon cancer cells. These findings provide new insights into the mechanisms by which TDA inhibits colon cancer and support clinical studies targeting endoplasmic reticulum stress pathways, and highlighting the role of autophagy inhibitors in optimizing cancer treatment.

Supplementary Materials: The following are available online at https:/ /www.mdpi.com/article/10 .3390/ijms22115566/s1.

Author Contributions: J.Q. performed the experiments and wrote the manuscript. C.Z., T.Z. and X.C. reviewed the manuscript and provided constructive suggestions. X.Y. and Z.L. analyzed data wrote, reviewed and revised the manuscript. All authors have read and agreed to the published version of the manuscript.

Funding: This work was supported by Natural Science Foundation Project of CQ CSTC' (Grant cstc2020jcyj-msxmX0154 to Zhenghong Lin), supported by the National Natural Science Foundation of China (Grant No. 31571454 to Zhenghong Lin, and 81872755 and 82073714 to Xiao-long Yang), and supported by the Talented Youth Cultivation Program from "the Fundamental Research Funds for the Central Universities", South-Central University for Nationalities (No. CZP20008 to Xiao-long Yang).

Institutional Review Board Statement: The study was conducted according to the guidelines of the Declaration of Helsinki, and approved by the Institutional Review Board of Chongqing University (protocol code: 2020039. approved on 10 September 2020).

Informed Consent Statement: Not applicable.

Data Availability Statement: Not applicable.

Acknowledgments: We thank the Analytical and Testing Center of Chongqing University for providing confocal fluorescence microscopy assistance.

Conflicts of Interest: The authors declare no conflict of interest. 


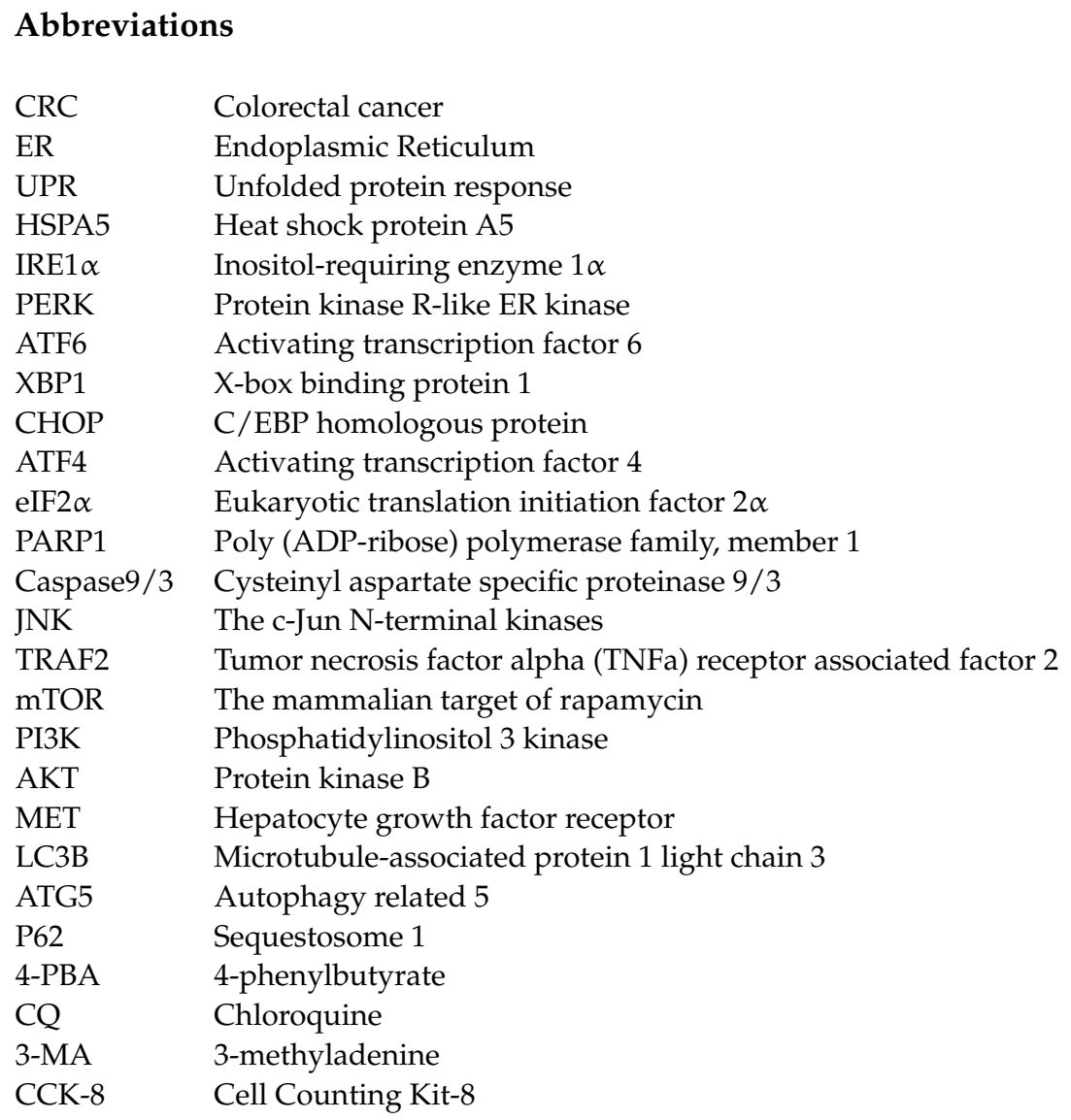

\section{References}

1. Bray, F.; Ferlay, J.; Soerjomataram, I.; Siegel, R.L.; Torre, L.A.; Jemal, A. Global cancer statistics 2018: GLOBOCAN estimates of incidence and mortality worldwide for 36 cancers in 185 countries. CA Cancer J. Clin. 2018, 68, 394-424. [CrossRef] [PubMed]

2. Zhu, J.; Tan, Z.; Hollis-Hansen, K.; Zhang, Y.; Yu, C.; Li, Y. Epidemiological Trends in Colorectal Cancer in China: An Ecological Study. Dig. Dis. Sci. 2016, 62, 235-243. [CrossRef] [PubMed]

3. Arnold, M.; Sierra, M.S.; Laversanne, M.; Soerjomataram, I.; Jemal, A.; Bray, F. Global patterns and trends in colorectal cancer incidence and mortality. Gut 2017, 66, 683-691. [CrossRef] [PubMed]

4. Dekker, E.; Tanis, P.J.; Vleugels, J.L.A.; Kasi, P.M.; Wallace, M.B. Colorectal cancer. Lancet 2019, 394, 1467-1480. [CrossRef]

5. Center, M.M.; Jemal, A.; Ward, E. International trends in colorectal cancer incidence rates. Cancer Epidemiol. Biomark. Prev. 2009, 18, 1688-1694. [CrossRef] [PubMed]

6. $\quad$ Franzese, C.; Comito, T.; Toska, E.; Tozzi, A.; Clerici, E.; De Rose, F.; Franceschini, D.; Navarria, P.; Reggiori, G.; Tomatis, S.; et al. Predictive factors for survival of oligometastatic colorectal cancer treated with Stereotactic body radiation therapy. Radiother. Oncol. 2019, 133, 220-226. [CrossRef]

7. Hadjipetrou, A.; Anyfantakis, D.; Galanakis, C.G.; Kastanakis, M.; Kastanakis, S. Colorectal cancer, screening and primary care: A mini literature review. World J. Gastroenterol. 2017, 23, 6049-6058. [CrossRef]

8. Valentini, V.; Morganti, A.G.; Gambacorta, M.A.; Mohiuddin, M.; Doglietto, G.B.; Coco, C.; De Paoli, A.; Rossi, C.; Di Russo, A.; Valvo, F.; et al. Preoperative hyperfractionated chemoradiation for locally recurrent rectal cancer in patients previously irradiated to the pelvis: A multicentric phase II study. Int. J. Radiat. Oncol. Biol. Phys. 2006, 64, 1129-1139. [CrossRef]

9. Banerjee, A.; Pathak, S.; Subramanium, V.D.; Dharanivasan, G.; Murugesan, R.; Verma, R.S. Strategies for targeted drug delivery in treatment of colon cancer: Current trends and future perspectives. Drug Discov. Today 2017, 22, 1224-1232. [CrossRef]

10. Jardim, D.L.; Rodrigues, C.A.; Novis, Y.A.S.; Rocha, V.G.; Hoff, P.M. Oxaliplatin-related thrombocytopenia. Ann. Oncol. 2012, 23, 1937-1942. [CrossRef]

11. Lee, C.S.; Ryan, E.J.; Doherty, G.A. Gastro-intestinal toxicity of chemotherapeutics in colorectal cancer: The role of inflammation. World J. Gastroenterol. 2014, 20, 3751-3761. [CrossRef]

12. Zhao, T.; Xu, L.-L.; Zhang, Y.; Lin, Z.-H.; Xia, T.; Yang, D.-F.; Chen, Y.-M.; Yang, X.-L. Three new $\alpha$-pyrone derivatives from the plant endophytic fungus Penicillium ochrochloronthe and their antibacterial, antifungal, and cytotoxic activities. J. Asian Nat. Prod. Res. 2018, 21, 851-858. [CrossRef] [PubMed]

13. Li, D.-L.; Chen, Y.-C.; Tao, M.-H.; Li, H.-H.; Zhang, W.-M. Two new octahydronaphthalene derivatives from Trichoderma spirale, an endophytic fungus derived from Aquilaria sinensis. Helv. Chim. Acta 2012, 95, 805-809. [CrossRef] 
14. Shiina, I.; Umezaki, Y.; Ohashi, Y.; Yamazaki, Y.; Dan, S.; Yamori, T. Total Synthesis of AMF-26, an Antitumor Agent for Inhibition of the Golgi System, Targeting ADP-Ribosylation Factor 1. J. Med. Chem. 2012, 56, 150-159. [CrossRef] [PubMed]

15. Ignashkova, T.I.; Gendarme, M.; Peschk, K.; Eggenweiler, H.M.; Lindemann, R.K.; Reiling, J.H. Cell survival and protein secretion associated with Golgi integrity in response to Golgi stress-inducing agents. Traffic 2017, 18, 530-544. [CrossRef]

16. Obata, Y.; Horikawa, K.; Shiina, I.; Takahashi, T.; Murata, T.; Tasaki, Y.; Suzuki, K.; Yonekura, K.; Esumi, H.; Nishida, T.; et al. Oncogenic Kit signalling on the Golgi is suppressed by blocking secretory trafficking with M-COPA in gastrointestinal stromal tumours. Cancer Lett. 2018, 415, 1-10. [CrossRef] [PubMed]

17. Watari, K.; Nakamura, M.; Fukunaga, Y.; Furuno, A.; Shibata, T.; Kawahara, A.; Hosoi, F.; Kuwano, T.; Kuwano, M.; Ono, M. The antitumor effect of a novel angiogenesis inhibitor (an octahydronaphthalene derivative) targeting both VEGF receptor and NF-kappaB pathway. Int. J. Cancer 2012, 131, 310-321. [CrossRef]

18. Hattori, T.; Watanabe-Takahashi, M.; Shiina, I.; Ohashi, Y.; Dan, S.; Nishikawa, K.; Yamori, T.; Naito, M. M-COPA, a novel Golgi system disruptor, suppresses apoptosis induced by Shiga toxin. Genes Cells 2016, 21, 901-906. [CrossRef]

19. Ohashi, Y.; Okamura, M.; Hirosawa, A.; Tamaki, N.; Akatsuka, A.; Wu, K.M.; Choi, H.W.; Yoshimatsu, K.; Shiina, I.; Yamori, T.; et al. M-COPA, a Golgi Disruptor, Inhibits Cell Surface Expression of MET Protein and Exhibits Antitumor Activity against MET-Addicted Gastric Cancers. Cancer Res. 2016, 76, 3895-3903. [CrossRef]

20. Ohashi, Y.; Iijima, H.; Yamaotsu, N.; Yamazaki, K.; Sato, S.; Okamura, M.; Sugimoto, K.; Dan, S.; Hirono, S.; Yamori, T. AMF-26, a novel inhibitor of the Golgi system, targeting ADP-ribosylation factor 1 (Arf1) with potential for cancer therapy. J. Biol. Chem. 2012, 287, 3885-3897. [CrossRef]

21. Schwarz, D.S.; Blower, M.D. The endoplasmic reticulum: Structure, function and response to cellular signaling. Cell Mol. Life Sci. 2016, 73, 79-94. [CrossRef] [PubMed]

22. Wang, M.; Kaufman, R.J. The impact of the endoplasmic reticulum protein-folding environment on cancer development. Nat. Rev. Cancer 2014, 14, 581-597. [CrossRef] [PubMed]

23. Stevenson, J.; Huang, E.Y.; Olzmann, J.A. Endoplasmic Reticulum-Associated Degradation and Lipid Homeostasis. Ann. Rev. Nutr. 2016, 36, 511-542. [CrossRef] [PubMed]

24. Hetz, C.; Chevet, E.; Oakes, S.A. Proteostasis control by the unfolded protein response. Nat. Cell Biol. 2015, 17, 829-838. [CrossRef] [PubMed]

25. Almanza, A.; Carlesso, A.; Chintha, C.; Creedican, S.; Doultsinos, D.; Leuzzi, B.; Luis, A.; McCarthy, N.; Montibeller, L.; More, S.; et al. Endoplasmic reticulum stress signalling_from basic mechanisms to clinical applications. FEBS J. 2019, 286, 241-278. [CrossRef] [PubMed]

26. Zhao, L.; Ackerman, S.L. Endoplasmic reticulum stress in health and disease. Curr. Opin. Cell Biol. 2006, 18, 444-452. [CrossRef] [PubMed]

27. Han, J.; Back, S.H.; Hur, J.; Lin, Y.H.; Gildersleeve, R.; Shan, J.; Yuan, C.L.; Krokowski, D.; Wang, S.; Hatzoglou, M.; et al. ER-stress-induced transcriptional regulation increases protein synthesis leading to cell death. Nat. Cell Biol. 2013, 15, 481-490. [CrossRef]

28. Tabas, I.; Ron, D. Integrating the mechanisms of apoptosis induced by endoplasmic reticulum stress. Nat. Cell Biol. 2011, 13, 184-190. [CrossRef] [PubMed]

29. Reid, D.W.; Chen, Q.; Tay, A.S.; Shenolikar, S.; Nicchitta, C.V. The unfolded protein response triggers selective mRNA release from the endoplasmic reticulum. Cell 2014, 158, 1362-1374. [CrossRef] [PubMed]

30. Hiramatsu, N.; Chiang, W.C.; Kurt, T.D.; Sigurdson, C.J.; Lin, J.H. Multiple Mechanisms of Unfolded Protein Response-Induced Cell Death. Am. J. Pathol. 2015, 185, 1800-1808. [CrossRef]

31. Bhat, T.A.; Chaudhary, A.K.; Kumar, S.; O’Malley, J.; Inigo, J.R.; Kumar, R.; Yadav, N.; Chandra, D. Endoplasmic reticulummediated unfolded protein response and mitochondrial apoptosis in cancer. Biochim. Biophys. Acta Rev. Cancer 2017, 1867, 58-66. [CrossRef]

32. Smith, M.H.; Ploegh, H.L.; Weissman, J.S. Road to ruin: Targeting proteins for degradation in the endoplasmic reticulum. Science 2011, 334, 1086-1090. [CrossRef] [PubMed]

33. Kaneko, M.; Nomura, Y. ER signaling in unfolded protein response. Life Sci. 2003, 74, 199-205. [CrossRef] [PubMed]

34. Walter, P.; Ron, D. The unfolded protein response: From stress pathway to homeostatic regulation. Science 2011, 334, 1081-1086. [CrossRef] [PubMed]

35. Rozpedek, W.; Pytel, D.; Mucha, B.; Leszczynska, H.; Diehl, J.A.; Majsterek, I. The Role of the PERK/eIF2alpha/ATF4/CHOP Signaling Pathway in Tumor Progression during Endoplasmic Reticulum Stress. Curr. Mol. Med. 2016, 16, 533-544. [CrossRef] [PubMed]

36. Calfon, M.; Zeng, H.; Urano, F.; Till, J.H.; Hubbard, S.R.; Harding, H.P.; Clark, S.G.; Ron, D. IRE1 couples endoplasmic reticulum load to secretory capacity by processing the XBP-1 mRNA. Nature 2002, 415, 92-96. [CrossRef]

37. Chen, Y.; Brandizzi, F. IRE1: ER stress sensor and cell fate executor. Trends Cell Biol. 2013, 23, 547-555. [CrossRef]

38. Teske, B.F.; Wek, S.A.; Bunpo, P.; Cundiff, J.K.; McClintick, J.N.; Anthony, T.G.; Wek, R.C. The eIF2 kinase PERK and the integrated stress response facilitate activation of ATF6 during endoplasmic reticulum stress. Mol. Biol. Cell 2011, 22, 4390-4405. [CrossRef]

39. Schonthal, A.H. Pharmacological targeting of endoplasmic reticulum stress signaling in cancer. Biochem. Pharmacol. 2013, 85, 653-666. [CrossRef] 
40. Lim, E.J.; Heo, J.; Kim, Y.H. Tunicamycin promotes apoptosis in leukemia cells through ROS generation and downregulation of survivin expression. Apoptosis 2015, 20, 1087-1098. [CrossRef] [PubMed]

41. Serrano-Negron, J.E.; Zhang, Z.; Rivera-Ruiz, A.P.; Banerjee, A.; Romero-Nutz, E.C.; Sanchez-Torres, N.; Baksi, K.; Banerjee, D.K. Tunicamycin-induced ER stress in breast cancer cells neither expresses GRP78 on the surface nor secretes it into the media. Glycobiology 2018, 28, 61-68. [CrossRef] [PubMed]

42. You, S.; Li, W.; Guan, Y. Tunicamycin inhibits colon carcinoma growth and aggressiveness via modulation of the ERK-JNKmediated AKT/mTOR signaling pathway. Mol. Med. Rep. 2018, 17, 4203-4212. [CrossRef] [PubMed]

43. Albayrak, D.; Doganlar, O.; Erdogan, S.; Merakli, M.; Dogan, A.; Turker, P.; Bostanci, A.; Doganlar, Z.B. Naringin Combined with NF-kappaB Inhibition and Endoplasmic Reticulum Stress Induces Apoptotic Cell Death via Oxidative Stress and the PERK/eIF2alpha/ATF4/CHOP Axis in HT29 Colon Cancer Cells. Biochem. Genet. 2021, 59, 159-184. [CrossRef] [PubMed]

44. Li, H.; Chen, H.; Li, R.; Xin, J.; Wu, S.; Lan, J.; Xue, K.; Li, X.; Zuo, C.; Jiang, W.; et al. Cucurbitacin I induces cancer cell death through the endoplasmic reticulum stress pathway. J. Cell Biochem. 2018, 120, 2391-2403. [CrossRef] [PubMed]

45. Kim, B.; Kim, J.; Kim, Y.S. Celecoxib induces cell death on non-small cell lung cancer cells through endoplasmic reticulum stress Anat. Cell Biol. 2017, 50, 293-300. [CrossRef] [PubMed]

46. Kim, I.; Xu, W.; Reed, J.C. Cell death and endoplasmic reticulum stress: Disease relevance and therapeutic opportunities. Nat. Rev. Drug Discov. 2008, 7, 1013-1030. [CrossRef]

47. Glick, D.; Barth, S.; Macleod, K.F. Autophagy: Cellular and molecular mechanisms. J. Pathol. 2010, 221, 3-12. [CrossRef]

48. Levine, B.; Kroemer, G. Autophagy in the pathogenesis of disease. Cell 2008, 132, 27-42. [CrossRef] [PubMed]

49. Mizushima, N.; Komatsu, M. Autophagy: Renovation of cells and tissues. Cell 2011, 147, 728-741. [CrossRef]

50. Jiang, F.; Zhou, J.Y.; Zhang, D.; Liu, M.H.; Chen, Y.G. Artesunate induces apoptosis and autophagy in HCT116 colon cancer cells, and autophagy inhibition enhances the artesunateinduced apoptosis. Int. J. Mol. Med. 2018, 42, 1295-1304.

51. Sui, X.; Chen, R.; Wang, Z.; Huang, Z.; Kong, N.; Zhang, M.; Han, W.; Lou, F.; Yang, J.; Zhang, Q.; et al. Autophagy and chemotherapy resistance: A promising therapeutic target for cancer treatment. Cell Death Dis. 2013, 4, e838. [CrossRef] [PubMed]

52. Wang, P.; Zhang, J.; Zhang, L.; Zhu, Z.; Fan, J.; Chen, L.; Zhuang, L.; Luo, J.; Chen, H.; Liu, L.; et al. MicroRNA 23b regulates autophagy associated with radioresistance of pancreatic cancer cells. Gastroenterology 2013, 145, 1133-1143 e12. [CrossRef]

53. Shi, T.T.; Yu, X.X.; Yan, L.J.; Xiao, H.T. Research progress of hydroxychloroquine and autophagy inhibitors on cancer. Cancer Chemother. Pharmacol. 2017, 79, 287-294. [CrossRef] [PubMed]

54. Burada, F.; Nicoli, E.R.; Ciurea, M.E.; Uscatu, D.C.; Ioana, M.; Gheonea, D.I. Autophagy in colorectal cancer: An important switch from physiology to pathology. World J. Gastrointest. Oncol. 2015, 7, 271-284. [CrossRef] [PubMed]

55. Devenport, S.N.; Shah, Y.M. Functions and Implications of Autophagy in Colon Cancer. Cells 2019, 8, 1349. [CrossRef] [PubMed]

56. Wu, Y.; Yao, J.; Xie, J.; Liu, Z.; Zhou, Y.; Pan, H.; Han, W. The role of autophagy in colitis-associated colorectal cancer. Signal Transduct. Target. Ther. 2018, 3, 31. [CrossRef]

57. Onorati, A.V.; Dyczynski, M.; Ojha, R.; Amaravadi, R.K. Targeting autophagy in cancer. Cancer 2018, 124, 3307-3318. [CrossRef]

58. White, E. The role for autophagy in cancer. J. Clin. Investig. 2015, 125, 42-46. [CrossRef]

59. Mokarram, P.; Albokashy, M.; Zarghooni, M.; Moosavi, M.A.; Sepehri, Z.; Chen, Q.M.; Hudecki, A.; Sargazi, A.; Alizadeh, J.; Moghadam, A.R.; et al. New frontiers in the treatment of colorectal cancer: Autophagy and the unfolded protein response as promising targets. Autophagy 2017, 13, 781-819. [CrossRef]

60. Verfaillie, T.; Salazar, M.; Velasco, G.; Agostinis, P. Linking ER Stress to Autophagy: Potential Implications for Cancer Therapy. Int. J. Cell Biol. 2010, 2010, 930590. [CrossRef]

61. Bejcek, J.; Spiwok, V.; Kmonickova, E.; Rimpelova, S. Na(+)/K(+)-ATPase Revisited: On Its Mechanism of Action, Role in Cancer, and Activity Modulation. Molecules 2021, 26, 1905. [CrossRef] [PubMed]

62. Rimpelova, S.; Zimmermann, T.; Drasar, P.B.; Dolensky, B.; Bejcek, J.; Kmonickova, E.; Cihlarova, P.; Gurska, S.; Kuklikova, L.; Hajduch, M.; et al. Steroid Glycosides Hyrcanoside and Deglucohyrcanoside: On Isolation, Structural Identification, and Anticancer Activity. Foods 2021, 10, 136. [CrossRef]

63. Skubnik, J.; Pavlickova, V.; Ruml, T.; Rimpelova, S. Current Perspectives on Taxanes: Focus on Their Bioactivity, Delivery and Combination Therapy. Plants (Basel) 2021, 10, 569. [CrossRef] [PubMed]

64. Gordaliza, M. Natural products as leads to anticancer drugs. Clin. Transl. Oncol. 2008, 9, 767-776. [CrossRef] [PubMed]

65. Newman, D.J.; Cragg, G.M.; Snader, K.M. The influence of natural products upon drug discovery. Nat. Prod. Rep. 2000, 17, 215-234. [CrossRef]

66. Qu, J.; Zou, T.; Lin, Z. The Roles of the Ubiquitin-Proteasome System in the Endoplasmic Reticulum Stress Pathway. Int. J. Mol. Sci. 2021, 22, 1526. [CrossRef] [PubMed]

67. Lee, A.S. GRP78 Induction in Cancer: Therapeutic and Prognostic Implications: Figure 1. Cancer Res. 2007, 67, 3496-3499. [CrossRef] [PubMed]

68. Jager, R.; Bertrand, M.J.; Gorman, A.M.; Vandenabeele, P.; Samali, A. The unfolded protein response at the crossroads of cellular life and death during endoplasmic reticulum stress. Biol. Cell 2012, 104, 259-270. [CrossRef] [PubMed]

69. Nishitoh, H. CHOP is a multifunctional transcription factor in the ER stress response. J. Biochem. 2011, 151, 217-219. [CrossRef]

70. Ma, Y.; Brewer, J.W.; Alan Diehl, J.; Hendershot, L.M. Two Distinct Stress Signaling Pathways Converge Upon the CHOP Promoter During the Mammalian Unfolded Protein Response. J. Mol. Biol. 2002, 318, 1351-1365. [CrossRef] 
71. Oyadomari, S.; Mori, M. Roles of CHOP/GADD153 in endoplasmic reticulum stress. Cell Death Differ. 2004, 11, 381-389. [CrossRef]

72. Thomas, S.; Sharma, N.; Golden, E.B.; Cho, H.; Agarwal, P.; Gaffney, K.J.; Petasis, N.A.; Chen, T.C.; Hofman, F.M.; Louie, S.G.; et al. Preferential killing of triple-negative breast cancer cells in vitro and in vivo when pharmacological aggravators of endoplasmic reticulum stress are combined with autophagy inhibitors. Cancer Lett. 2012, 325, 63-71. [CrossRef] [PubMed]

73. Pahl, H.L. Signal transduction from the endoplasmic reticulum to the cell nucleus. Physiol. Rev. 1999, 79, 683-701. [CrossRef] [PubMed]

74. Denmeade, S.R.; Jakobsen, C.M.; Janssen, S.; Khan, S.R.; Garrett, E.S.; Lilja, H.; Christensen, S.B.; Isaacs, J.T. Prostate-specific antigen-activated thapsigargin prodrug as targeted therapy for prostate cancer. J. Natl. Cancer Inst. 2003, 95, 990-1000. [CrossRef]

75. Banerjee, A.; Lang, J.-Y.; Hung, M.-C.; Sengupta, K.; Banerjee, S.K.; Baksi, K.; Banerjee, D.K. Unfolded Protein Response Is Required in nu/nu Mice Microvasculature for Treating Breast Tumor with Tunicamycin. J. Biol. Chem. 2011, 286, 29127-29138. [CrossRef] [PubMed]

76. Gorska, M.; Popowska, U.; Sielicka-Dudzin, A.; Kuban-Jankowska, A.; Sawczuk, W.; Knap, N.; Cicero, G.; Wozniak, F. Geldanamycin and its derivatives as Hsp90 inhibitors. Front. Biosci. 2012, 17, 2269-2277. [CrossRef]

77. Carew, J.S.; Nawrocki, S.T.; Krupnik, Y.V.; Dunner, K., Jr.; McConkey, D.J.; Keating, M.J.; Huang, P. Targeting endoplasmic reticulum protein transport: A novel strategy to kill malignant B cells and overcome fludarabine resistance in CLL. Blood 2006, 107, 222-231. [CrossRef]

78. Casanova, J.E. Regulation of Arf activation: The Sec7 family of guanine nucleotide exchange factors. Traffic 2007, 8, 1476-1485. [CrossRef]

79. Ohuchi, K.; Takahashi, C.; Hirasawa, N.; Watanabe, M.; Fujiki, H.; Tsurufuji, S. Stimulation of histamine release and arachidonic acid metabolism in rat peritoneal mast cells by thapsigargin, a non-TPA-type tumor promoter. Biochim. Biophys. Acta 1989, 1003, 9-14. [CrossRef]

80. Lee, J.-S.; Zheng, Z.; Mendez, R.; Ha, S.-W.; Xie, Y.; Zhang, K. Pharmacologic ER stress induces non-alcoholic steatohepatitis in an animal model. Toxicol. Lett. 2012, 211, 29-38. [CrossRef]

81. Nawrocki, S.T.; Carew, J.S.; Pino, M.S.; Highshaw, R.A.; Dunner, K., Jr.; Huang, P.; Abbruzzese, J.L.; McConkey, D.J. Bortezomib sensitizes pancreatic cancer cells to endoplasmic reticulum stress-mediated apoptosis. Cancer Res. 2005, 65, 11658-11666. [CrossRef] [PubMed]

82. Nawrocki, S.T.; Carew, J.S.; Dunner, K., Jr.; Boise, L.H.; Chiao, P.J.; Huang, P.; Abbruzzese, J.L.; McConkey, D.J. Bortezomib inhibits PKR-like endoplasmic reticulum (ER) kinase and induces apoptosis via ER stress in human pancreatic cancer cells. Cancer Res. 2005, 65, 11510-11519. [CrossRef] [PubMed]

83. Levy, J.M.M.; Towers, C.G.; Thorburn, A. Targeting autophagy in cancer. Nat. Rev. Cancer 2017, 17, 528-542. [CrossRef] [PubMed]

84. Livesey, K.M.; Tang, D.; Zeh, H.J.; Lotze, M.T. Autophagy inhibition in combination cancer treatment. Curr. Opin. Investig. Drugs 2009, 10, 1269-1279. [PubMed]

85. Garrido, W.; Rocha, J.D.; Jaramillo, C.; Fernandez, K.; Oyarzun, C.; San Martin, R.; Quezada, C. Chemoresistance in high-grade gliomas: Relevance of adenosine signalling in stem-like cells of glioblastoma multiforme. Curr. Drug Targets 2014, 15, 931-942. [CrossRef]

86. Degenhardt, K.; Mathew, R.; Beaudoin, B.; Bray, K.; Anderson, D.; Chen, G.; Mukherjee, C.; Shi, Y.; Gelinas, C.; Fan, Y.; et al. Autophagy promotes tumor cell survival and restricts necrosis, inflammation, and tumorigenesis. Cancer Cell 2006, 10, 51-64. [CrossRef]

87. Kim, T.W.; Lee, S.Y.; Kim, M.; Cheon, C.; Ko, S.G. Kaempferol induces autophagic cell death via IRE1-JNK-CHOP pathway and inhibition of G9a in gastric cancer cells. Cell Death Dis. 2018, 9, 875. [CrossRef]

88. Tsai, D.H.; Chung, C.H.; Lee, K.T. Antrodia cinnamomea induces autophagic cell death via the CHOP/TRB3/Akt/mTOR pathway in colorectal cancer cells. Sci. Rep. 2018, 8, 17424. [CrossRef]

89. Jiang, X.; Overholtzer, M.; Thompson, C.B. Autophagy in cellular metabolism and cancer. J. Clin. Investig. 2015, 125, 47-54. [CrossRef] [PubMed]

90. Hensley, K.; Harris-White, M.E. Redox regulation of autophagy in healthy brain and neurodegeneration. Neurobiol. Dis. 2015, 84, 50-59. [CrossRef]

91. Guo, M.L.; Liao, K.; Periyasamy, P.; Yang, L.; Cai, Y.; Callen, S.E.; Buch, S. Cocaine-mediated microglial activation involves the ER stress-autophagy axis. Autophagy 2015, 11, 995-1009. [CrossRef] [PubMed]

92. Dong, L.; Yu, L.; Bai, C.; Liu, L.; Long, H.; Shi, L.; Lin, Z. USP27-mediated Cyclin E stabilization drives cell cycle progression and hepatocellular tumorigenesis. Oncogene 2018, 37, 2702-2713. [CrossRef] [PubMed]

93. Yu, L.; Dong, L.; Li, H.; Liu, Z.; Luo, Z.; Duan, G.; Dai, X.; Lin, Z. Ubiquitination-mediated degradation of SIRT1 by SMURF2 suppresses CRC cell proliferation and tumorigenesis. Oncogene 2020, 39, 4450-4464. [CrossRef]

94. Lin, Z.; Yang, H.; Tan, C.; Li, J.; Liu, Z.; Quan, Q.; Kong, S.; Ye, J.; Gao, B.; Fang, D. USP10 antagonizes c-Myc transcriptional activation through SIRT6 stabilization to suppress tumor formation. Cell Rep. 2013, 5, 1639-1649. [CrossRef] [PubMed] 